\title{
Loss of mTORC1 signaling alters pancreatic $\alpha$ cell mass and impairs glucagon secretion
}

\author{
Nadejda Bozadjieva,, ${ }^{1,2}$ Manuel Blandino-Rosano, ${ }^{1,3}$ Jennifer Chase, ${ }^{2}$ Xiao-Qing Dai, ${ }^{4}$ Kelsey Cummings, ${ }^{1}$ Jennifer Gimeno, ${ }^{3}$ \\ Danielle Dean, ${ }^{5}$ Alvin C. Powers, ${ }^{5,6,7}$ George K. Gittes, ${ }^{8}$ Markus A. Rüegg, ${ }^{9}$ Michael N. Hall, ${ }^{9}$ Patrick E. MacDonald, ${ }^{4}$ \\ and Ernesto Bernal-Mizrachi'1,2,30 \\ 'Department of Internal Medicine, Division of Metabolism, Endocrinology and Diabetes, and ²Graduate Program in Cellular and Molecular Biology, University of Michigan, Ann Arbor, Michigan, USA. \\ ${ }^{3}$ Department of Internal Medicine, Division Endocrinology, Metabolism and Diabetes, Miller School of Medicine, University of Miami, Miami, Florida, USA. ${ }^{4}$ Alberta Diabetes Institute and Department of \\ Pharmacology, Edmonton, Alberta, Canada. ${ }^{5}$ Department of Medicine, Division of Diabetes, Endocrinology, and Metabolism, and ${ }^{6}$ Department of Molecular Physiology \& Biophysics, Vanderbilt University, \\ Nashville, Tennessee, USA. ${ }^{7}$ VA Tennessee Valley Healthcare, Nashville, Tennessee, USA. ${ }^{8}$ Children's Hospital, University of Pittsburgh School of Medicine, Pittsburgh, Pennsylvania, USA. ${ }^{9}$ Biozentrum, \\ University of Basel, Basel, Switzerland. ${ }^{10}$ Veterans Affairs Medical Center, Miami, Florida, USA.
}

\begin{abstract}
Clucagon plays a major role in the regulation of glucose homeostasis during fed and fasting states. However, the mechanisms responsible for the regulation of pancreatic $\alpha$ cell mass and function are not completely understood. In the current study, we identified mTOR complex 1 (mTORC1) as a major regulator of $\alpha$ cell mass and glucagon secretion. Using mice with tissuespecific deletion of the mTORC1 regulator Raptor in $\alpha$ cells ( $\alpha$ Raptor $\left.{ }^{\mathrm{K}}\right)$, we showed that mTORC1 signaling is dispensable for $\alpha$ cell development, but essential for $\alpha$ cell maturation during the transition from a milk-based diet to a chow-based diet after weaning. Moreover, inhibition of mTORC1 signaling in $\alpha$ Raptor ${ }^{\mathrm{KO}}$ mice and in WT animals exposed to chronic rapamycin administration decreased glucagon content and glucagon secretion. In $\alpha$ Raptor ${ }^{\mathrm{KO}}$ mice, impaired glucagon secretion occurred in response to different secretagogues and was mediated by alterations in $\mathrm{K}_{\text {ATP }}$ channel subunit expression and activity. Additionally, our data identify the mTORC1/FoxA2 axis as a link between mTORC1 and transcriptional regulation of key genes responsible for $\alpha$ cell function. Thus, our results reveal a potential function of mTORC1 in nutrient-dependent regulation of glucagon secretion and identify a role for mTORC1 in controlling $\alpha$ cell-mass maintenance.
\end{abstract}

\section{Introduction}

Type 1 (T1D) and type 2 diabetes (T2D) are characterized by uncontrolled hyperglycemia associated with the progressive decrease in insulin. Glucagon, insulin's counterregulatory hormone, plays a major role in maintaining glucose homeostasis by promoting glucose production via hepatic glycogenolysis and gluconeogenesis. Glucagon levels are elevated in insulin-resistant/nondiabetic T1D and T2D patients, leading to enhanced hepatic glucose output and thereby exacerbating hyperglycemia (1-3). On the contrary and much less understood is the failure of $\alpha$ cells to secrete glucagon in response to hypoglycemia. This presents a major limiting factor for optimal glucose control in T1D diabetes or advanced T2D patients (4-6). Thus, a better understanding of the molecular mechanisms governing glucagon levels could have major implications in understanding abnormal responses to hypoglycemia in diabetes and provide novel avenues for diabetes management.

Mice with loss of the insulin receptor in $\alpha$ cells have increased fed glucagon levels, suggesting that insulin signaling mediates the suppression of glucagon secretion in the fed state (7). In addition,

Conflict of interest: The authors have declared that no conflict of interest exists. License: This work is licensed under the Creative Commons Attribution 4.0 International License. To view a copy of this license, visit http://creativecommons.org/ licenses/by/4.0/.

Submitted: August 16, 2016; Accepted: September 26, 2017.

Reference information: J Clin Invest. 2017;127(12):4379-4393.

https://doi.org/10.1172/JCI90004. mice with pancreatic deletion of the insulin receptor substrate 2 (IRS2) exhibit decreased $\alpha$ cell mass and lower glucagon protein and RNA levels, implicating IRS signaling in the control of $\alpha$ cell mass and glucagon expression (8). Insulin inhibits glucagon gene transcription and secretion and promotes $\alpha$ cell proliferation by activation of IRS2/PI3K/Akt signaling $(9,10)$. $\alpha$ Cell proliferation is reduced by treatment with the mTOR complex 1 (mTORC1) inhibitor rapamycin, suggesting that downstream of the insulin receptor mTORC1 mediates the effects of insulin on $\alpha$ cell mass and glucagon secretion $(11,12)$. The amino acids arginine, alanine, and glutamine potentiate glucagon secretion and this effect is suppressed by high glucose in an insulin-independent manner (13). Recent studies demonstrate that interruption of glucagon receptor signaling by genetic inactivation or treatment with small molecules or glucagon receptor antibodies increases amino acid availability and leads to increased $\alpha$ cell proliferation in an mTORdependent manner $(12,14-17)$. These findings support the concept that $\alpha$ cell mass and glucagon secretion are sensitive to extracellular signals including nutrients (amino acids, glucose) and growth factors (insulin) and that the mTORC1 pathway may be involved as a downstream regulator of one or both of these processes. However, how downstream targets of nutrient or insulin receptor signaling regulate $\alpha$ cell mass and glucagon secretion in vivo is currently unknown.

To investigate the importance of endogenous mTORC1 function in $\alpha$ cell mass and glucagon secretion, we generated mice with tissue-specific deletion of Raptor in $\alpha$ cells. Our data uncovered 
A

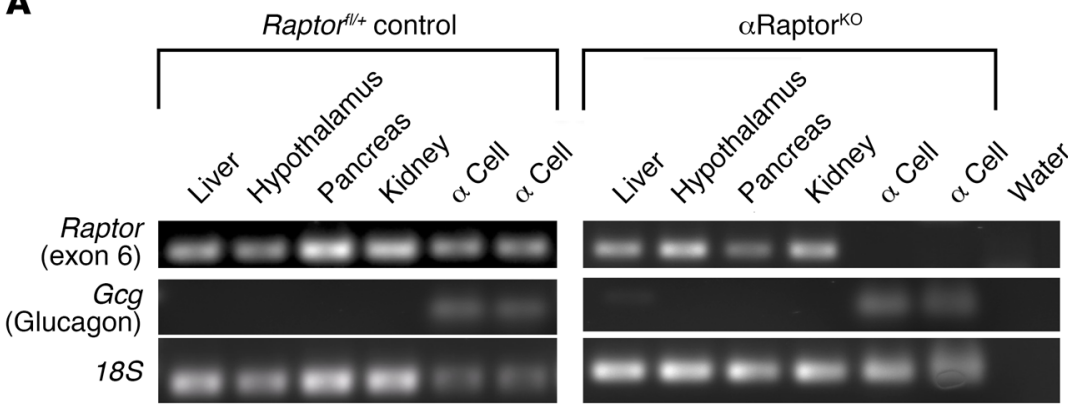

$\mathbf{B}$

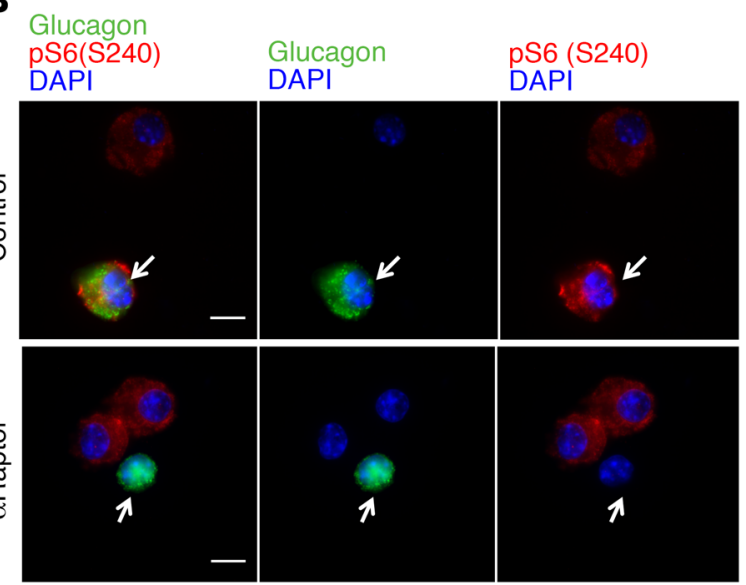

C
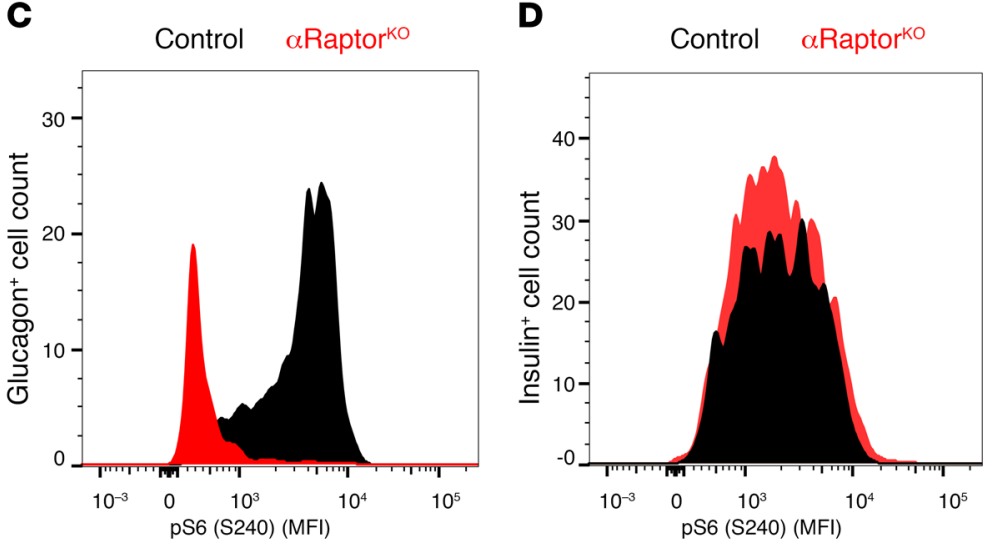

Figure 1. Loss of Raptor and mTORC1 activity in $\alpha$ cells of $\alpha$ Raptor ${ }^{\mathrm{k} 0}$ mice. (A) Nested RTPCR amplification of Raptor exon 6 (flanked exon) in tissues and single $\alpha$ cells from control and $\alpha$ Raptor ${ }^{\mathrm{KO}}$ mice was performed as described in Methods. (B) Immunofluorescent staining for mTORC1 activity in $\alpha$ cells assessed by phospho-S6 (Ser240) and glucagon staining in dispersed islets from 1-month-old control and $\alpha$ Raptor ${ }^{\mathrm{KO}}$ mice. Scale bars: $10 \mu \mathrm{m}$. (C) Assessment of phospho-S6 (Ser240) staining by flow cytometry in glucagon-positive cells from young control and $\alpha$ Raptor ${ }^{\mathrm{KO}}$ mice $(n=3-4)$. (D) Flow cytometric analysis showing preserved mTORC1 activity by phospho-S6 (Ser240) in insulin-positive cells of young $\alpha$ Raptorko mice $(n=3-4)$. MFI, mean fluorescence intensity.

a potentially novel role of $\mathrm{mTORC} 1$ in maintenance of postnatal $\alpha$ cell mass and identified a previously unknown function of this pathway on glucagon secretion during fasting and hypoglycemia by modulation of $\mathrm{K}_{\text {ATP }}$ channel subunit expression (SUR1 and Kir6.2) and channel activity. We also discovered that mTORC1 positively regulates FoxA2 levels, a known regulator of SUR1, Kir6.2, and glucagon transcription, providing a link between mTORC1 and transcription of critical $\alpha$ cell genes. This work provides insights into how nutrient-dependent glucagon secretion and $\alpha$ cell mass are regulated and suggest that pharmacologic inhibition of this pathway using immunosuppressant medications, such as everolimus or rapamycin, could alter glucagon levels and glucose homeostasis.

\section{Results}

Lack of mTORC1 signaling after deletion of Raptor in a cells. $\alpha$ Cell-specific deletion of Raptor was achieved by crossing glucagon-Cre and Raptorfl/fl mice $\left(\alpha\right.$ Raptor $\left.^{\mathrm{KO}}\right)(18,19)$. Deletion of flanked exon 6 exclusively in $\alpha$ cells from $\alpha$ Raptor $^{\mathrm{KO}}$ mice was demonstrated by nested reverse transcription PCR (RT-PCR) for exon 6 using different tissues and single $\alpha$ cells (Figure 1A) (19). Loss of mTORC1 signaling was confirmed by lack of phospho-S6 (Ser240) immunofluorescence staining only in glucagon-positive cells in dispersed islets from 1-month-old $\alpha$ Raptor ${ }^{\mathrm{KO}}$ mice (Figure 1B). To validate the reduction in mTORC1 signaling in $\alpha$ cells from $\alpha$ Raptor ${ }^{\mathrm{KO}}$ mice, we assessed phospho-S6 (Ser240), glucagon, and insulin staining in dispersed islets by flow cytometry using quantitative mean fluorescence intensity (MFI). Figure 1C shows pS6 MFI levels in $\alpha$ cells (glucagon $^{+}$cell count) and Figure 1D includes pS6 MFI levels in $\beta$ cells (insulin ${ }^{+}$cell count). Phospho-S6 (Ser240) levels were nearly lost in glucagon-positive cells from $\alpha$ Raptor ${ }^{\mathrm{KO}}$ mice (red curve) compared with controls (black curve) (Figures $1 \mathrm{C})$. In contrast, the MFI for phospho-S6 (Se240) was similar in insulin-positive cells from $\alpha$ Raptor $^{\mathrm{KO}}$ mice (red curve) and controls (black curve) (Figure 1D). Recombination efficiency of glucagon-Cre assessed by crossing these mice to reporter mice showed that Cre-mediated recombination was achieved in the majority of $\alpha$ cells $(84.2 \% \pm 6.4 \%, n=4)$. We also report glucagonCre recombination in neurons of the nucleus of the solitary tract (nucleus tractus solitarius, NTS) (Supplemental Figure 1; supplemental material available online with this article; https:/doi. org/10.1172/JCI90004DS1).

Low fed and fasting glucagon levels in mice with loss of mTORC1 signaling in a cells. Body weight and random-fed blood glucose were not different between control mice and $\alpha$ Raptor ${ }^{\mathrm{KO}}$ or $\alpha$ Raptor $^{\mathrm{HET}}$ (glucagon-Cre; Raptor ${ }^{\mathrm{fl} /+}$ ) mice (Figure 2, A and B). Glucose tolerance at 2 and 8 months of age was not different between the 3 groups (Figure 2, C and G). Control mice exhibited a decrease in glucose levels after 12 hours of fasting at both 2 and 8 months of age (Figure 2, D and H). In contrast, 2-month-old $\alpha$ Raptor $^{\mathrm{KO}}$ mice were able to maintain blood glucose levels during the first 12 hours of fasting and glucose almost returned to the levels of control mice at 24 hours (Figure 2D and 

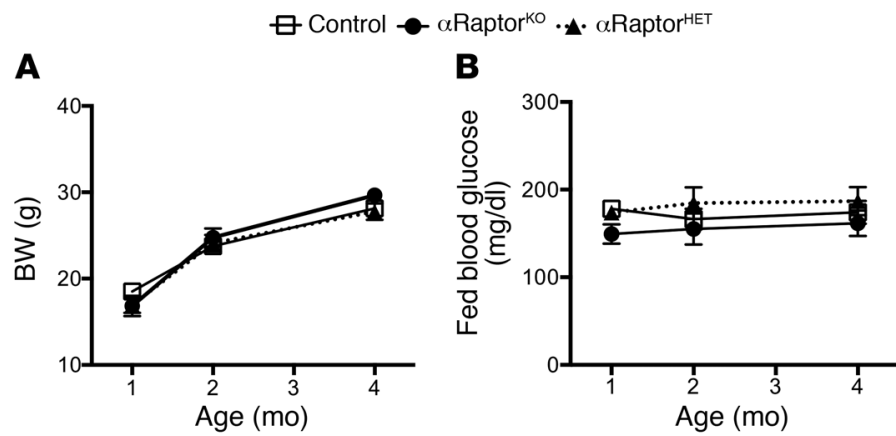

Figure 2. Mice with loss of mTORC1 signaling in $\alpha$ cells exhibit low fed and fasting glucagon levels. (A) Body weight and (B) random-fed blood glucose levels in control, $\alpha$ Raptor ${ }^{\mathrm{KO}}$, and $\alpha$ Raptor $^{\mathrm{HET}}$ mice $(n=9)$. (C) Intraperitoneal glucose tolerance test in 2-month-old $(n=3-4)$ and (C) 8-month-old control, $\alpha$ Raptor ${ }^{\mathrm{KO}}$, and $\alpha$ Raptor ${ }^{\mathrm{HET}}$ mice $(n=5-8)$. (D) Fasting blood glucose in 2-month-old ( $n=7-9)$ and (H) 8-month-old $(n=3-4)$ control, $\alpha$ Raptor $^{\mathrm{KO}}$, and $\alpha$ Raptor ${ }^{\mathrm{HET}}$ mice. (E) Fed and fasted glucagon levels in 2-month-old ( $n=5-6)$ and (I) 8-month-old $(n=5-6)$ control, $\alpha$ Raptor ${ }^{k 0}$, and $\alpha$ Raptor ${ }^{H E T}$ mice. (F) Fed and fasted insulin levels in 2-month-old $(n=3-4)$ and $(\mathrm{J})$ 8-month-old mice $(n=4)$. Data are shown as means \pm SEM. ${ }^{*} P \leq 0.05$ (1-way ANOVA with Dunnett's post-test).
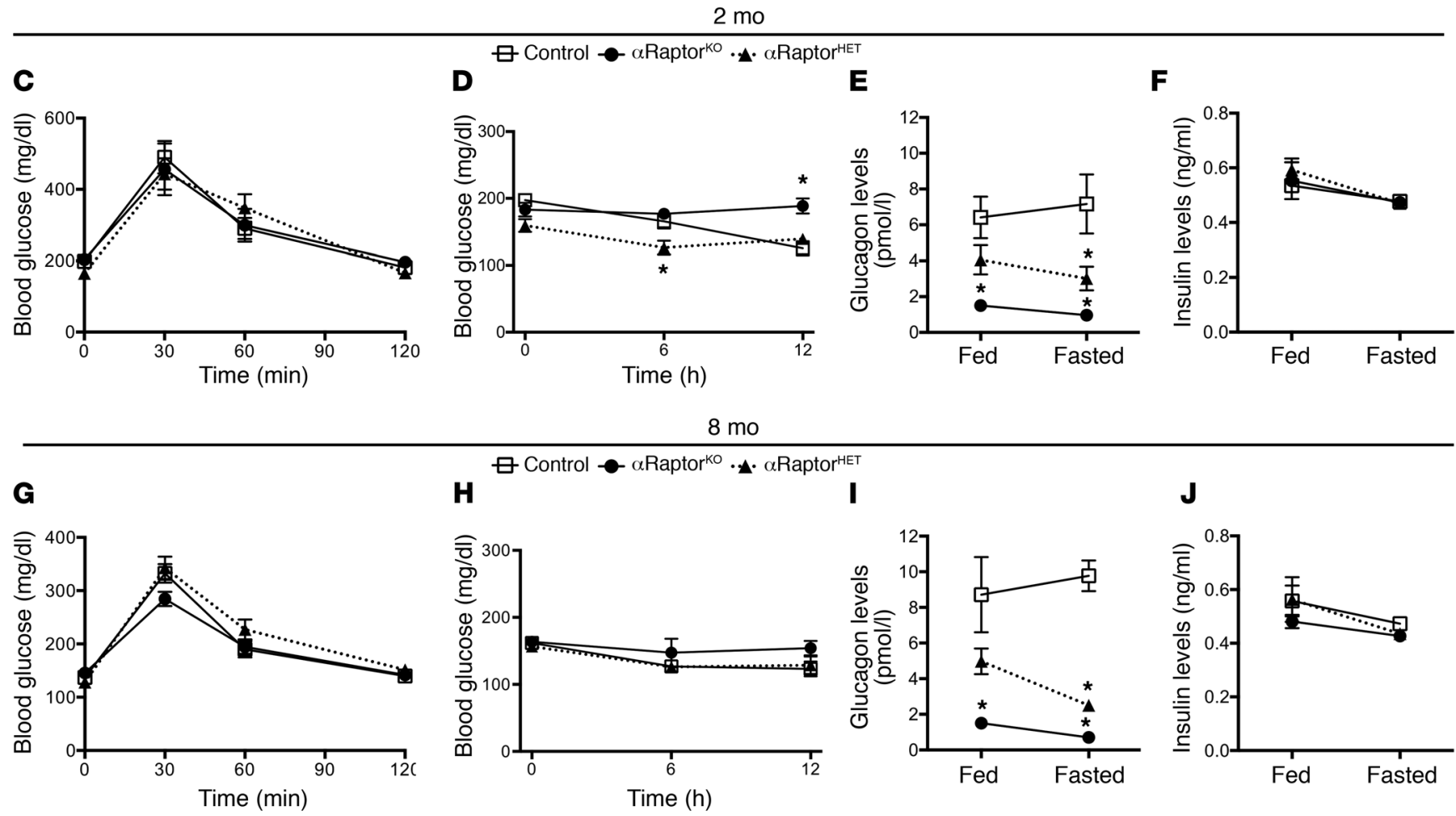

Supplemental Figure 2A). $\alpha$ Raptor ${ }^{\mathrm{KO}}$ mice showed increased glucose levels after intraperitoneal pyruvate injection, implying that increased gluconeogenesis could play a role in the resistance of $\alpha$ Raptor ${ }^{\mathrm{KO}}$ mice to a decrease in blood glucose during fasting (Supplemental Figure 2B). Consistent with this, liver weight and glycogen content decreased, but tended to be higher in $\alpha$ Raptor ${ }^{\mathrm{KO}}$ after overnight fasting (Supplemental Figure 2, C and D). The results of these studies suggest that $\alpha$ Raptor ${ }^{\mathrm{KO}}$ mice were more resistant to a decrease in glucose during the first 12 hours of fasting by increased gluconeogenic pathways, but these mechanisms were less effective after prolonged fasting (24 hours). Examination of glucose during fasting at 8 months of age showed a similar reduction in fasting glucose among all groups (Figure 2H). Assessment of glucagon in the fed and fasting states showed lower fed and fasting glucagon levels in $\alpha$ Raptor $^{\mathrm{KO}}$ mice at 2 and 8 months of age (Figure 2, E and I). Interestingly, fed and fasted glucagon levels were also reduced in $\alpha$ Raptor $^{\mathrm{HET}}$ mice at 2 and 8 months, but not to the level observed in the $\alpha$ Raptor ${ }^{\mathrm{KO}}$ mice (Figure 2, E and I). A trend towards increased glucagon levels was observed in 2- and 8-month-old control mice in response to fasting (Figure 2E). Compared with controls, glucagon levels decreased after 12-hour fasting in young and old $\alpha$ Raptor $^{\mathrm{KO}}$ and $\alpha$ Raptor $^{\mathrm{HET}}$ mice (Figure 2, E and I). No differences were observed in fed or fasting insulin levels between controls, $\alpha$ Raptor $^{\mathrm{KO}}$, and $\alpha$ Raptor $^{\mathrm{HET}}$ mice at 2 and 8 months (Figure 2, $\mathrm{F}$ and J). Finally, assessment of GLP-1 levels showed no difference in fed or fasting circulating active GLP- 1 between $\alpha$ Raptor $^{\mathrm{KO}}, \alpha$ Raptor $^{\mathrm{HET}}$, and controls at 2 months of age (Supplemental Figure 3A). Active GLP-1 levels in intestinal extracts from 2-month-old mice showed no differences between control and $\alpha$ Raptor ${ }^{\mathrm{KO}}$ mice, suggesting that intestinal enteroendocrine cells expressing GLP-1 were conserved, perhaps due to mosaic Cre-mediated recombination in intestinal stem cells (Supplemental Figure 3B).

mTORC1 signaling is necessary for the maintenance of postnatal $\alpha$ cells. Morphometric analysis at postnatal day 1 (newborn) demonstrated that $\alpha$ Raptor ${ }^{\mathrm{KO}}$ mice were born with normal $\alpha$ cell mass (Figure 3, A and B, $\alpha$ cells depicted with white arrows). At 2 weeks of age, $\alpha$ Raptor ${ }^{\mathrm{KO}}$ mice exhibited normal $\alpha$ cell mass, lower levels of proliferation (assessed by Ki67), and no changes in apoptosis (assessed by TUNEL) (Figure 3C and Supplemental Figure 4, A and B). $\alpha$ Raptor ${ }^{\mathrm{KO}}$ mice displayed loss of $\alpha$ cells as evidenced by a reduction in $\alpha$ cell mass starting at 1 month of age (Figure 3, A and $\mathrm{D} ; \alpha$ cells depicted with white arrows in $3 \mathrm{~A}$ ). Flow cytometric 
A
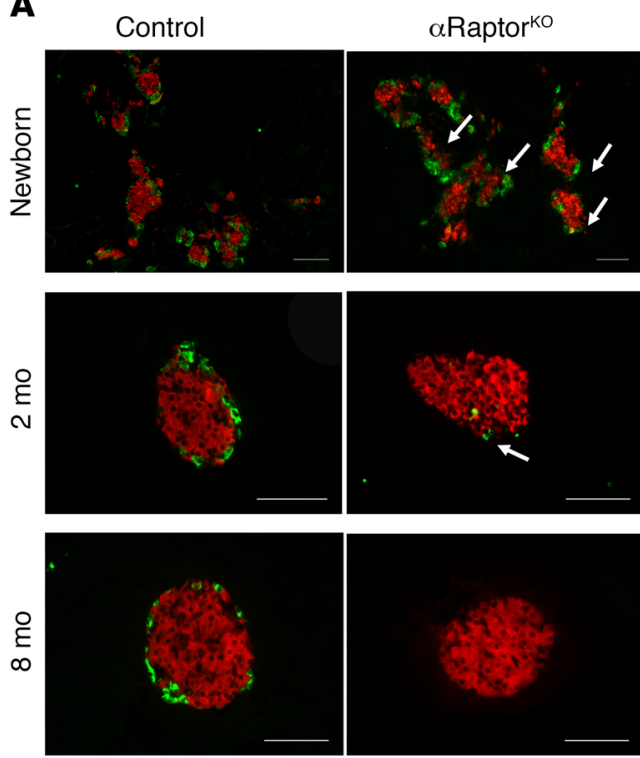

Glucagon Insulin

$\mathbf{K}$

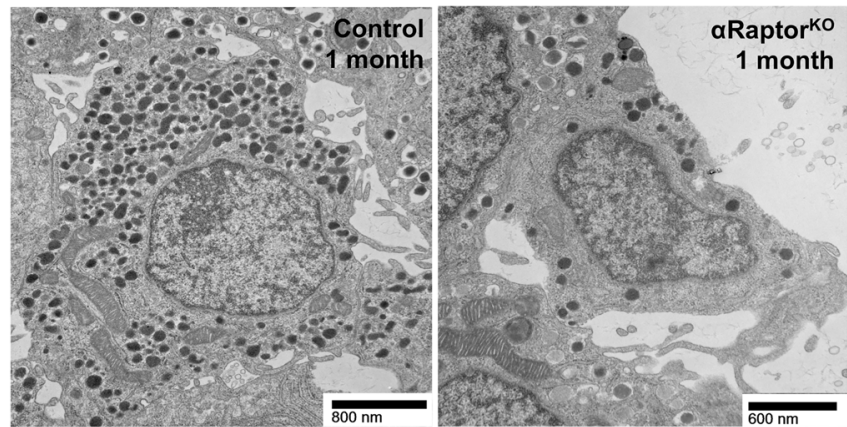

$\mathbf{L}$

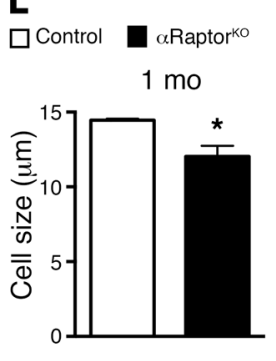

M

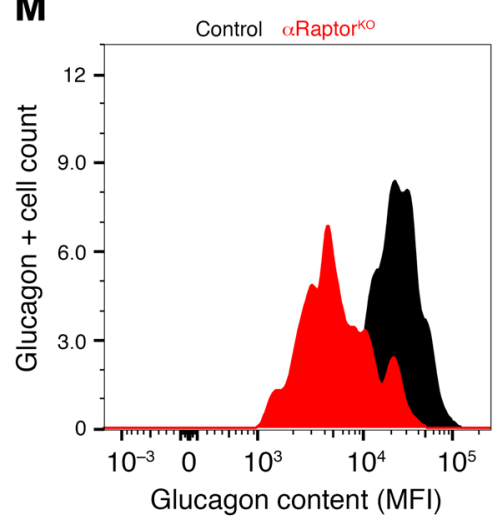

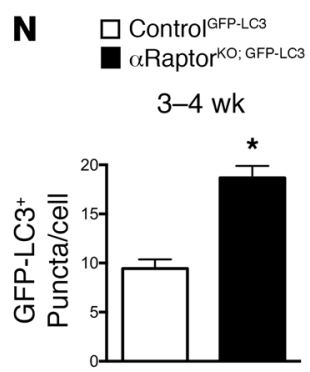
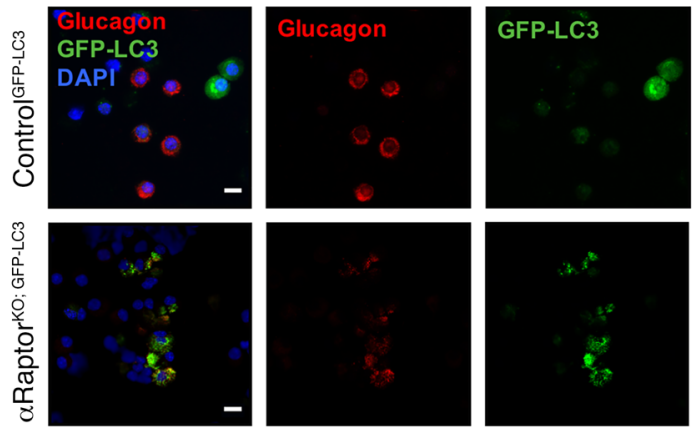

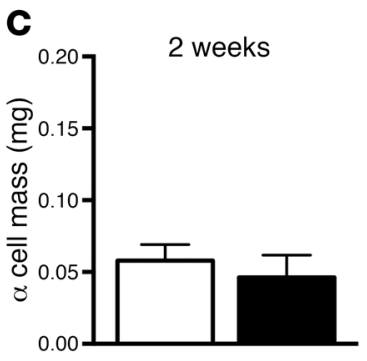

D

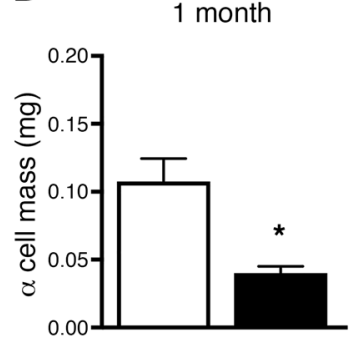

$\mathbf{F}$

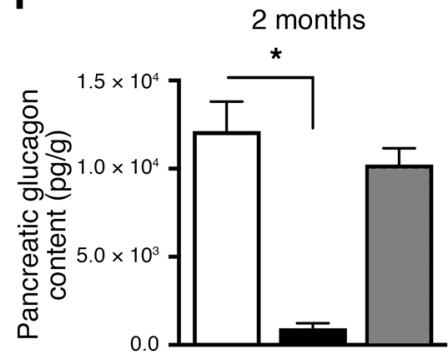

E

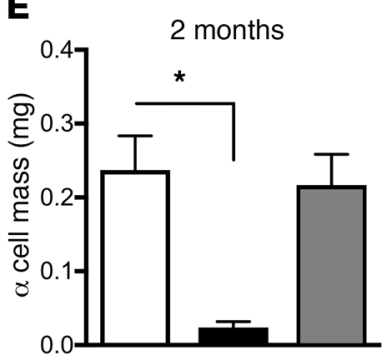

G

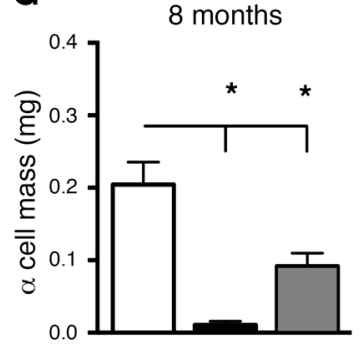

H

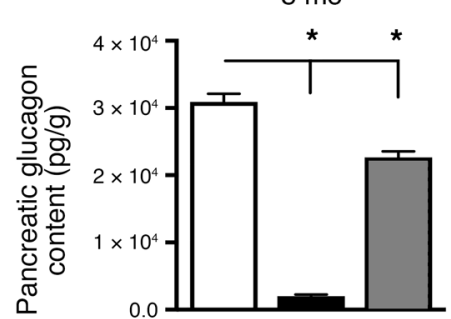

I

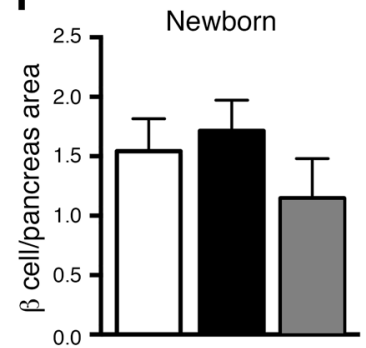

J

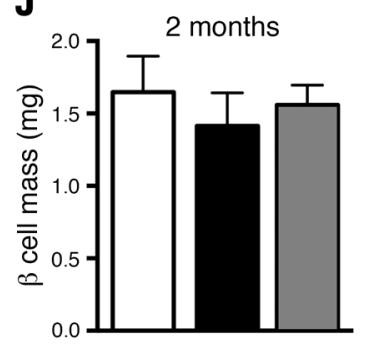


Figure 3. mTORC1 signaling is necessary for maintenance of postnatal $\alpha$ cells. (A) Immunofluorescent staining for insulin and glucagon in pancreatic sections from control, $\alpha$ Raptor ${ }^{\mathrm{KO}}$, and $\alpha$ Raptor ${ }^{\mathrm{HET}}$ mice ( $\alpha$ cells depicted with white arrows). Scale bars: $50 \mu \mathrm{m}$. (B) Quantification of $\alpha$ cell fraction at postnatal day 1 (newborn) control, $\alpha$ Raptor ${ }^{\mathrm{KO}}$, and $\alpha$ Raptor ${ }^{\mathrm{HET}}$ mice $(n=3)$. (C) Quantification of $\alpha$ cell mass at 2 weeks $(n=4)$, (D) in 1-monthold $(n=4)$, and (E) 2-month-old control, $\alpha$ Raptor $^{\mathrm{KO}}$, and $\alpha$ Raptor $^{\mathrm{HET}}$ mice ( $n=4-5)$. (F) Pancreatic glucagon content $(n=4-6)$ in 2-month-old mice. (C) Quantification of $\alpha$ cell mass $(n=3-4)$ and $(\mathbf{H})$ pancreatic glucagon content ( $n=3-4)$ in 8-month-old mice. (I) Quantification of $\beta$ cell fraction at postnatal day 1 (newborn) $(n=3)$ and $(J) \beta$ cell mass in 2-month-old mice $(n=4-5)$. (K) Electron microscopy of $\alpha$ cells from 1-month-old control and $\alpha$ Raptor ${ }^{\mathrm{kO}}$ mice. Scale bars: $800 \mathrm{~nm}$ (control) and $600 \mathrm{~nm}\left(\alpha\right.$ Raptor ${ }^{\mathrm{kO}}$ ). (L) Quantification of $\alpha$ cell size by morphometric analysis in control and $\alpha$ Raptor ${ }^{\mathrm{KO}}$ mice at 1 month of age $(n=3)$. (M) Analysis of glucagon content by flow cytometric analysis in dispersed $\alpha$ cells from control and $\alpha$ Raptor ${ }^{K 0}$ mice at 3 weeks of age $(n=3-4)$. MFI, mean fluorescence intensity. (N) Quantification of GFP-LC3 puncta and representative images of dispersed $\alpha$ cells from 3-week-old control and $\alpha$ Raptor ${ }^{\mathrm{KO}}$ mice ( $n=50$ cells) crossed to an in vivo reporter of autophagy (GFP-LC3 mice). Scale bars: $10 \mu \mathrm{m}$. Data for $\mathbf{C}, \mathbf{D}, \mathbf{L}$, and $\mathbf{N}$ are shown as means \pm SEM. ${ }^{*} P \leq 0.05$ (Student's 2-tailed $t$ test). Data for $\mathbf{B}$ and $\mathbf{E}-\mathbf{J}$ are shown as means $\pm \mathrm{SEM}$. ${ }^{*} P \leq 0.05$ (1-way ANOVA with Dunnett's post-test)

analysis showed that the reduction of $\alpha$ cell mass at 1 month of age resulted from increased apoptosis (assessed by annexin V) and a trend towards decreased proliferation (assessed by Ki67) (Supplemental Figure 4, C and D). $\alpha$ Cell mass progressively decreased in $\alpha$ Raptor ${ }^{\mathrm{KO}}$ mice at 2 and 8 months (Figure 3, A, E, and G). A progressive decline in total pancreatic glucagon content was also observed at 2 and 8 months (Figure $3, \mathrm{~F}$ and $\mathrm{H}$ ). In contrast, $\beta, \delta$ (somatostatin), and pancreatic polypeptide (PP) cell mass were not altered in 2-month-old $\alpha$ Raptor ${ }^{\mathrm{KO}}$ mice (Figure 3, I and $\mathrm{J}$ and Supplemental Figure 4, E-G). $\alpha$ Cell mass and pancreatic glucagon content were comparable between controls and in $\alpha$ Raptor ${ }^{\mathrm{HET}}$ mice at 2 months of age (Figure 3, E and F). However, by 8 months $\alpha$ Raptor $^{\mathrm{HET}}$ mice showed a reduction in $\alpha$ cell mass and pancreatic glucagon content (Figure 3, G and H). The number of $\alpha$ cells in older $\alpha$ Raptor $^{\mathrm{HET}}$ mice assessed by flow cytometry was reduced, confirming these results (Supplemental Figure 4J). However, cell size and cellular glucagon content measured by flow cytometry was unaltered in the remaining $\alpha$ cells of $\alpha$ Raptor ${ }^{\mathrm{HET}}$ mice (Supplemental Figure 4, D and E). Electron microscopy in 1-month-old $\alpha$ Raptor $^{\mathrm{KO}}$ showed a reduction in $\alpha$ cell size that was confirmed by cell size measurements (Figure 3, $\mathrm{K}$ and $\mathrm{L}$ ). In addition, the number of glucagon granules appeared reduced in $\alpha$ cells from $\alpha$ Raptor ${ }^{\mathrm{KO}}$ mice and this was independently validated by reduced intracellular glucagon levels using flow cytometry (Figure 3M). Given the known role of mTORC1 in autophagy, we designed experiments to examine the contribution of autophagy to the loss of $\alpha$ cells in $\alpha$ Raptor ${ }^{\mathrm{KO}}$ mice by crossing to an in vivo reporter of autophagy (GFP-LC3 mice) (20). These studies showed that $\alpha$ Raptor ${ }^{\mathrm{KO}}$ exhibited increased GFP-LC3 puncta in $\alpha$ cells, consistent with the presence of increased autophagy (Figure 3N). Taken together, the results of these studies suggest that reduction in $\alpha$ cell mass between 2 and 4 weeks results from a combination of decreased proliferation and increased apoptosis.

$\alpha$ Raptor ${ }^{H E T}$ mice have decreased glucagon responses to hypoglycemia and glucoprivic conditions. The lower fasting glucagon levels with concomitant normal $\alpha$ cell mass in 2-month-old $\alpha$ Raptor ${ }^{\mathrm{HET}}$ mice suggested that these mice exhibited a defect in glucagon secretion. To further investigate the role of MTORC1 in glucagon secretion, we subjected these mice to different stimulatory conditions in vivo. Examination of glucagon secretion by insulin-induced hypoglycemia in 2-month-old mice showed that insulin induced similar decreases in blood glucose in aRaptor ${ }^{\mathrm{KO}}$, $\alpha$ Raptor $^{\mathrm{HET}}$, and control mice (Figure 4A). However, glucagon secretion after insulin-induced hypoglycemia was compromised in $\alpha$ Raptor ${ }^{\mathrm{KO}}$ mice and this was likely explained by the severe loss of $\alpha$ cell mass (Figure $4 \mathrm{~B}$ ). In contrast, $\alpha$ Raptor ${ }^{\mathrm{HET}}$ mice were able to respond, but showed reduced glucagon secretion at 30 minutes after insulin injection (Figure 4B). Next, we examined glucagon secretion under glucoprivic signals induced by 2-deoxy-D-glucose (2DG) injection, a nonmetabolizable glucose analog that inhibits phosphorylation of glucose by hexokinase (Figure 4C). 2DG administration raises blood glucose by increases in counterregulatory hormones (epinephrine, corticosterone, and glucagon) and hepatic glucose output. Assessment of glucagon secretion after 2DG injection showed that $\alpha$ Raptor ${ }^{\mathrm{KO}}$ failed to respond to glucoprivic conditions, a defect that was likely due to severe loss of $\alpha$ cell mass. (Figure $4 \mathrm{D}) . \alpha$ Raptor $^{\mathrm{HET}}$ mice displayed impaired glucagon responses compared with the controls at 30 minutes after 2DG injection (Figure 4D). Interestingly, $\alpha$ Raptor $^{\mathrm{HET}}$ mice had a higher response in blood glucose output at 30 minutes, suggesting that compensatory counterregulatory responses could be enhanced in conditions of chronic low glucagon (Figure 4D). These data further showed that $\alpha$ Raptor ${ }^{\mathrm{HET}}$ mice have a defect in glucagon secretion.

Rapamycin treatment in vivo inhibits glucagon secretory responses to hypoglycemia and reduces glucagon content in isolated islets. To validate the alterations in glucagon secretion observed in $\alpha$ Raptor ${ }^{\text {HET }}$ mice, we assessed the effect of pharmacologic inhibition of mTORC1 by intraperitoneal administration of rapamycin to wildtype mice every other day for total of 5 injections (Figure 5A). Body weight and fed blood glucose were not affected by rapamycin or vehicle treatment (Figure 5, B and C). After insulin-induced hypoglycemia, rapamycin-treated mice displayed lower glucose at 120 minutes after insulin injection, suggesting a decrease in counterregulatory responses to hypoglycemia (Figure 5D). Evaluation of the glucagon response in these mice revealed that glucagon secretory response to hypoglycemia was blunted (Figure 5E) and glucagon content in isolated islets was reduced in rapamycin-treated mice (Figure 5F). In order to avoid confounding factors that result from systemic actions of rapamycin, we measured glucagon secretion in wild-type islets after acute exposure to rapamycin. In these studies, wild-type islets were preincubated with $30 \mathrm{nM}$ rapamycin for 30 minutes followed by a 2-hour incubation with different glucose concentrations from $1 \mathrm{mM}$ to $24 \mathrm{mM}$. As expected, glucagon secretion decreased with higher glucose concentrations in untreated control islets (Figure 5G). However, 30 minutes of rapamycin treatment decreased glucagon secretion at $1 \mathrm{mM}$ glucose, confirming in vivo data showing that rapamycin inhibits glucagon secretion in response to hypoglycemia (Figure 5G). In addition, glucagon secretion was suppressed by increasing glucose conditions and this effect was not altered by rapamycin. The reduction in glucagon secretion induced by acute treatment with rapamycin was not explained by alterations in glucagon content (Figure $5 \mathrm{H}$ ), suggesting that shortterm rapamycin treatment can inhibit glucagon secretion induced 
A

Ð Control $\bullet \alpha$ Raptor $^{\mathrm{ko}} \cdot \boldsymbol{\star} \cdot \alpha$ RaptoHET
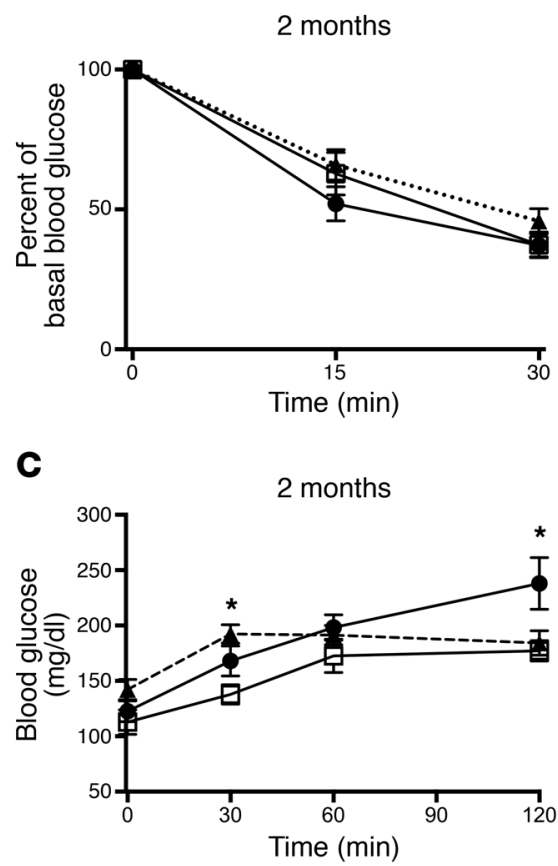

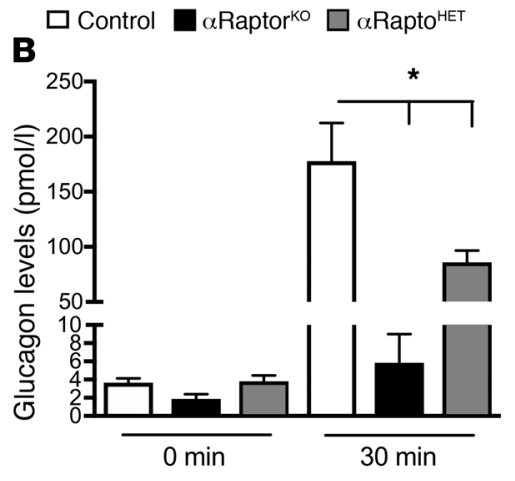

D

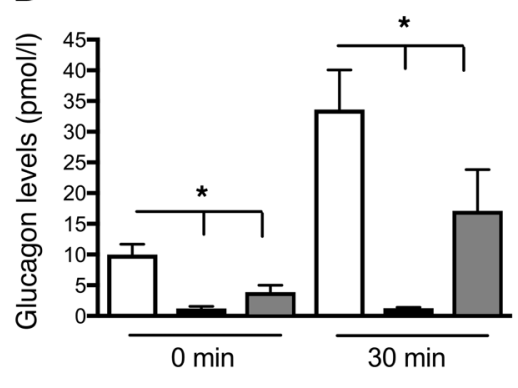

Figure 4. $\alpha$ Raptor ${ }^{\mathrm{HET}}$ mice exhibit decreased glucagon responses to hypoglycemia and glucoprivic conditions. (A) Glucose levels after intraperitoneal injection of insulin in 2-month-old control, $\alpha$ Raptor $^{\mathrm{KO}}$, and $\alpha$ Raptor $^{\mathrm{HET}}$ mice $(n=5-6)$. (B) Glucagon levels measured in the same group of mice at 0 and 30 minutes after insulin injection $(1 \mathrm{U} / \mathrm{kg})$ $(n=5-6)$. (C) Blood glucose levels after intraperitoneal injection of 2-deoxy-D-glucose $(150 \mathrm{mg} / \mathrm{kg})$ in 2-month-old control, $\alpha$ Raptor $^{\mathrm{KO}}$, and $\alpha$ Raptor ${ }^{\mathrm{HET}}$ mice $(n=4-5)$. (D) Glucagon levels at 0 and 30 minutes after 2-deoxy-D-glucose in the same group of mice $(n=4)$. Data are shown as means \pm SEM. ${ }^{*} P \leq 0.05$ (1-way ANOVA with Dunnett's post-test). by low glucose independently of alterations in glucagon content. Similarly, glutamine also failed to stimulate glucagon secretion in wild-type islets also treated acutely with rapamycin (30 nM), and these changes were independent of glucagon content (Supplemental Figure 5, A and B).

Glucagon secretory responses induced by pharmacologic manipulation of $K_{A T P}$ channels in $\alpha$ Raptor ${ }^{H E T}$ islets is abnormal. To uncover the mechanisms responsible for impaired glucagon secretion in $\alpha$ Raptor ${ }^{\mathrm{HET}}$ mice, we examined secretory responses of isolated islets. Glucagon secretion in response to depolarization induced by potassium chloride $(\mathrm{KCl} ; 30 \mathrm{mM})$ was similar between control and $\alpha$ Raptor ${ }^{\mathrm{HET}}$ islets (Figure $6 \mathrm{~A}$ ). Next, we examined the glucagon response to arginine, a secretagogue that induces glucagon secretion in part by modulating $\mathrm{K}_{\mathrm{ATP}}$ channels (21). Glucagon secretion induced by arginine was blunted in $\alpha$ Raptor $^{\mathrm{HET}}$ islets (Figure $6 \mathrm{~B}$ ). Taken together, these data suggested that the defect in glucagon secretion in $\alpha$ Raptor $^{\mathrm{HET}}$ mice resided in steps prior to cell depolarization and possibly at the level of the $\mathrm{K}_{\mathrm{ATP}}$ channel. We further evaluated glucagon secretion during pharmacological modulation of $\mathrm{K}_{\text {ATP }}$ channel activity with increasing concentrations of tolbutamide $\left(\mathrm{K}_{\mathrm{ATP}}\right.$ channel antagonist) and diazoxide $\left(\mathrm{K}_{\mathrm{ATP}}\right.$ channel agonist). Under low-glucose conditions, when a relatively larger fraction of $\mathrm{K}_{\mathrm{ATP}}$ channels are open, tolbutamide treatment of control islets induced glucagon secretion up to concentrations of $10 \mu \mathrm{M}$, whereas glucagon secretion was inhibited at higher concentrations, as previously described (22-24). In contrast, tolbutamide treatment of $\alpha$ Raptor $^{\mathrm{HET}}$ islets failed to induce glucagon secretion and suppressed glucagon release at lower concentrations of tolbutamide (Figure 6C). Next we tested the effects of diazoxidemediated opening of $\mathrm{K}_{\text {ATP }}$ channels at high glucose, where most $\mathrm{K}_{\text {ATP }}$ channels should be closed. Increasing concentrations of diazoxide $(0-10 \mu \mathrm{M})$ relieved the suppression of glucagon secre- tion in control islets (Figure 6D). In contrast, islets from $\alpha$ Raptor ${ }^{\mathrm{HET}}$ mice were unresponsive to diazoxide and this agent failed to induce glucagon secretion (Figure 6D). Conversely, under lowglucose $(1 \mathrm{mM})$ conditions when at least some $\mathrm{K}_{\text {ATP }}$ channels are open, diazoxide further induced glucagon secretion at $1 \mu \mathrm{M}$ followed by a dose-dependent suppression at 10 and $100 \mu \mathrm{M}$ in control islets (Figure 6E). Under this condition, $\alpha$ Raptor $^{\mathrm{HET}}$ islets still failed to respond to diazoxide (Figure 6, D and E). Taken together, these studies suggested that $\mathrm{K}_{\text {ATP }}$ channel function is altered in $\alpha$ cells with reduced mTORC1 signaling.

mTORC1 positively regulates glucagon secretion by modulating $K_{A T P}$ channel expression. Next, we tested whether the changes in glucagon secretion obtained by pharmacologic manipulation of $\mathrm{K}_{\text {ATP }}$ channels in $\alpha$ Raptor ${ }^{\mathrm{HET}}$ mice resulted from alterations in $\mathrm{K}_{\mathrm{ATP}}$ channel activity. Whole-cell patch clamp was performed on $\alpha$ cells at low glucose from Glucagon-Cre ${ }^{\text {tdTomato }}$ and $\alpha$ Raptor $^{\text {HET;tdTomato }}$ mice expressing a fluorescent reporter in $\alpha$ cells. Following establishment of the whole-cell patch clamp, and subsequent washout of intracellular ATP, $\mathrm{K}_{\mathrm{ATP}}$ channel current was significantly reduced in $\alpha$ Raptor $^{\mathrm{HET}} \alpha$ cells compared with controls (Figure 6, F and G). To test the hypothesis that these results could be explained by alterations in $\mathrm{K}_{\mathrm{ATP}}$ subunit expression, we measured the expression of $\mathrm{K}_{\text {ATP }}$ channels subunits Kir6.2 and sulfonylurea receptor subunit 1 (SUR1) in $\alpha$ cells. We isolated an enriched population of $\alpha$ cells by FACS using dispersed islets from $\alpha$ Raptor $^{\mathrm{HET}}$ and control mice crossed to Ins1-EGFP and CAG-tdTomato reporter mice (refer to Methods and Supplemental Figure 6). Our data showed that the enriched $\alpha$ cell population from $\alpha$ Raptor ${ }^{\mathrm{HET}}$ had decreased SUR1 and Kir6. 2 mRNA expression (Figure 6H). Supporting these findings, single-cell mRNA expression for SUR1 in $\alpha$ cells also showed that young $\alpha$ Raptor ${ }^{\text {KO; } \text { tdTomato }}$ mice had fewer $\alpha$ cells positive for SUR1 (Figure 6I). Unfortunately, we were unable to detect expres- 
Table 1. Fluidigm single-cell analysis of $\alpha$ cells from 3-week-old control and $\alpha$ Raptor $^{\mathrm{k} 0}$ mice

\begin{tabular}{lcc}
\multicolumn{1}{r}{ Gene } & Fold Change & $\boldsymbol{P}$ value \\
Ulk2 & -12.79 & 0.002431 \\
SNAP25 & -11.28 & 0.002376 \\
\hline Foxa2 & -5.52 & 0.012191 \\
\hline Neurog3 & -5.18 & 0.000242 \\
\hline Abcc8 (SUR1) & -4.66 & 0.018140 \\
Notch1 & -4.46 & 0.001665 \\
Cata4 & -4.09 & 0.000713 \\
XBP1 & -4.04 & 0.048825 \\
Chrm3 & -3.84 & 0.000087 \\
Mafb & -3.75 & 0.007382 \\
Pou3f4 & -3.71 & 0.016007 \\
\hline Lamtor1 & -3.56 & 0.000370 \\
Nkx2-2 & -3.14 & 0.000418 \\
Ccnb1 & -3.00 & 0.000003 \\
Cacna1s & -2.92 & 0.030182 \\
Eif4e & -2.88 & 0.000065 \\
Rbpj & -2.65 & 0.017525 \\
Ulk1 & -2.50 & 0.000574 \\
Kcnj11 (Kir6.2) & -2.29 & 0.016501 \\
Hsp90ab1 & -1.76 & 0.027254 \\
\hline ACcg & -57.57 & 0.001473
\end{tabular}

Fluidigm single-cell analysis of $\alpha$ cells from 3-week-old control and $\alpha$ Raptor ${ }^{\mathrm{KO}}$ mice ( $n=3-6$ mice). Fold change and $P$ value of differentially expressed genes identified in single cells (Student's 2-tailed t test and ${ }^{A}$ MAST analysis)

sion of Kir6.2 in single cells using this methodology. Lastly, we measured mRNA and protein in $\alpha \mathrm{TC}-1$ cells, a glucagon-expressing cell line, treated with rapamycin $(30 \mathrm{nM})$ for 48 hours. These studies showed that inhibiting mTORC1 signaling leads to decreased KIR6.2 and SUR1 protein and mRNA levels (Figure 6, J and K). Overall, our data showed that mTORC1 positively regulates the expression of $\mathrm{K}_{\text {ATP }}$ channels in $\alpha$ cells and this could explain in part the decrease in $\mathrm{K}_{\mathrm{ATP}}$ channel current in $\alpha$ Raptor ${ }^{\mathrm{HET}} \alpha$ cells.

Single-cell $m R N A$ expression in a cells from $\alpha$ Raptor ${ }^{K O}$ mice reveals alterations in critical a cell genes. To validate the expression studies and further explore the mechanisms linking mTORC1 to regulation of $\alpha$ cell function and mass, we assessed expression of critical $\alpha$ cell genes using the Fluidigm $\mathrm{C} 1$ platform for RNA expression of single pancreatic islet cells (refer to Supplemental Table 3 for the list of genes analyzed). We analyzed an enriched population of $\alpha$ cells by FACS using dispersed islets from 3-week-old $\alpha$ Raptor ${ }^{\mathrm{KO}}$ and control mice crossed to Ins1-EGFP and CAG-tdTomato reporter mice, and further sorted these cells based on viability. Single-cell gene analysis validated the decrease in SUR1 and Kir6.2 expression in $\alpha$ cells from young $\alpha$ Raptor ${ }^{\mathrm{KO}}$ and further showed reduced Gcg (glucagon) gene expression in these mice (Figure 7A and Table 1). Autophagy-associated genes Ulk1 and Ulk2 were decreased in $\alpha$ Raptor $^{\mathrm{KO}}$, confirming a known role of this pathway in autophagy. Importantly, gene expression of key transcription factors involved in $\alpha$ cell development and maintenance, such as FoxA2, Neurogen3, Gata4, MafB, Pou3f4, Notch1, Rbpj, and Nkx2.2, were lower in $\alpha$ Raptor $^{\mathrm{KO}}$ compared with control $\alpha$ cells (Figure 7A and Table
1). Decreased expression of Ccnb1 (cyclin B) and EIF4E suggests that these genes could be involved in the alteration of $\alpha$ cell proliferation seen in $\alpha$ Raptor $^{\mathrm{KO}}$. Single-cell gene analysis also identified targets involved in exocytosis and glucagon secretion, such as SNAP25 (synaptosomal-associated protein 25), Cacna1s (L-type voltage-dependent calcium channel) and Chrm 3 (muscarinic acetylcholine M3 receptor). Endoplasmic reticulum stress-associated genes, XBP1 and Hsp9Oab1, were also decreased in aRaptor ${ }^{\mathrm{KO}}$. FoxA2, Nkx2.2, and Pou3f4 expression was also decreased in $\alpha \mathrm{TC}-1$ cells treated with rapamycin $(30 \mathrm{nM})$ for 48 hours, validating the results obtained by the single-cell analysis (Figure 7B).

The reduction in FoxA2 expression in $\alpha$ cells from $\alpha$ Raptor ${ }^{\mathrm{KO}}$ was particularly interesting, as FoxA2 has been shown to directly promote Gcg, SUR1, and Kir6.2 gene transcription in $\alpha$ cells (2529). Therefore, we hypothesized that mTORC1 positively modulates glucagon and $\mathrm{K}_{\text {АTP }}$ channel expression through regulation of FoxA2 expression. Flow cytometric analysis confirmed that FoxA2 protein levels were also reduced in $\alpha$ cells from young $\alpha$ Raptor ${ }^{\mathrm{KO}}$ mice (Figure 7, C and D). In addition, nuclear FoxA2 levels were decreased, as measured by the ratio of signal intensity of nuclear FoxA2 over 4',6-diamidino-2-phenylindole (DAPI) in the $\alpha$ cells from young control and $\alpha$ Raptor ${ }^{\mathrm{KO}}$ mice (Figure $7, \mathrm{E}$ and $\mathrm{F}$ ).

\section{Discussion}

The current studies extend previous reports by uncovering potentially novel insights into the regulation of glucagon secretion and $\alpha$ cell mass by mTORC1 signaling using mice with tissuespecific deletion of Raptor in $\alpha$ cells. This work demonstrates that mTORC1 signaling positively regulates $\alpha$ cell-mass maintenance and glucagon secretion during fasting, hypoglycemia, and glucoprivic signals. Our data show that MTORC1 is dispensable for $\alpha$ cell development, but plays a role in the maintenance of $\alpha$ cells after weaning. Importantly, these experiments uncover a potentially novel role of mTORC1 signaling in the regulation of glucagon secretion by transcriptional regulation of $\mathrm{K}_{\text {ATP }}$ channel subunit expression. We also present a potentially novel role of mTORC1 in controlling critical transcription factors in $\alpha$ cells and identified FoxA2 as a potentially novel mTORC1 target. More importantly, the decrease in glucagon secretion and glucagon content by lack of mTORC1 activity was recapitulated by administration of the clinically used immunosuppressant and $\mathrm{mTORC} 1$ inhibitor, rapamycin. Rapalogs (rapamycin analogs including everolimus) are FDA-approved drugs that suppress mTORC1 activity and are routinely used as immunosuppressants in transplantation and for the treatment of several malignancies including insulinomas. Our data suggest that these mechanisms could negatively regulate glucagon levels in vivo and thus inhibit glucagon responses to hypoglycemia in patients taking these medications.

Morphologic studies showed that the decrease in glucagon levels observed in $\alpha$ Raptor ${ }^{\mathrm{KO}}$ mice resulted from a loss of $\alpha$ cells after weaning (Figure 3, B-D). Interestingly, no changes in $\beta$ cell mass were observed in $\alpha$ Raptor ${ }^{\mathrm{KO}}$ mice, suggesting that $\alpha$ cell loss in $\alpha$ Raptor $^{\mathrm{KO}}$ mice has minor contributions to $\beta$ cell maintenance during normal conditions. The $\alpha$ cell dynamics associated with loss of mTORC1 signaling are interesting and suggest that mTORC1 is dispensable for $\alpha$ cell developmental programs, but play critical roles during the suckling-weaning transition state 
$\mathbf{A}$

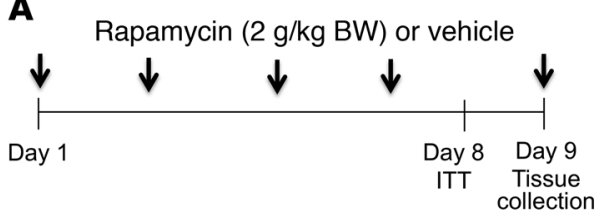

B

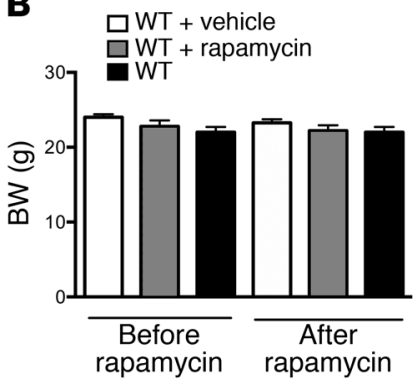

c

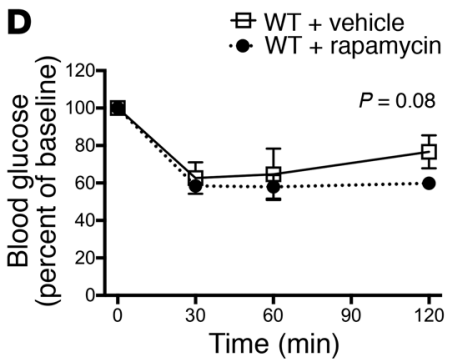

G

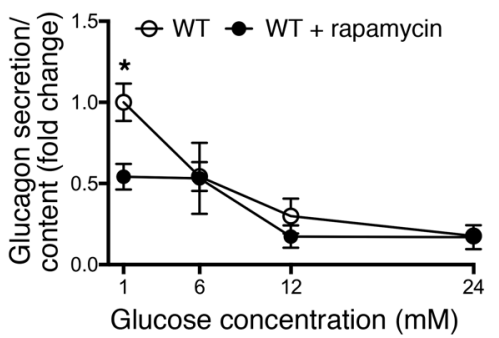

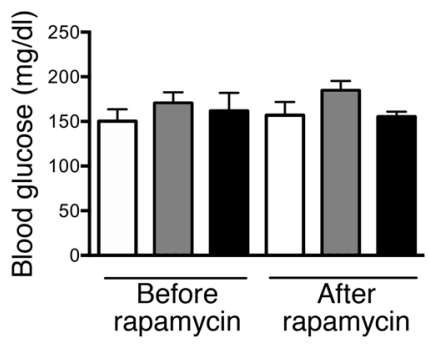

E

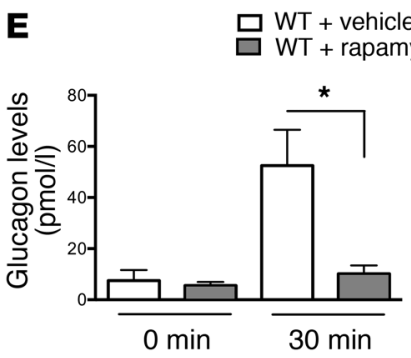

H

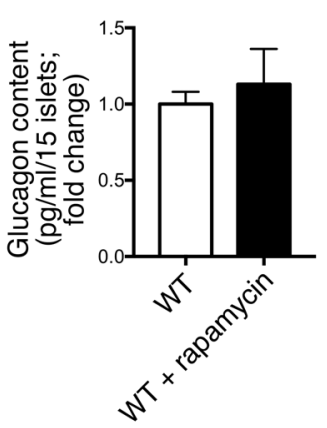

Figure 5. Rapamycin treatment in vivo inhibits glucagon secretory responses to hypoglycemia and reduces glucagon content. (A) Experimental design used for administration of rapamycin to 2-month-old wild-type (WT) male mice. Intraperitoneal administration of rapamycin $(2 \mathrm{~g} / \mathrm{kg})$ or vehicle control was performed every other day for 9 days (arrows). ITT, insulin tolerance test. (B) Body weight and (C) fed glucose levels before rapamycin treatment and day 8 of rapamycin treatment of WT treated with vehicle and WT treated with rapamycin $(n=4-5)$. (D) Glucose levels after intraperitoneal injection of insulin $(1 \mathrm{U} / \mathrm{kg})$ in WT treated with vehicle and WT treated with rapamycin for 8 days $(n=4-5)$. (E) Glucagon levels at 0 and 30 minutes after insulin injection in the same group of mice $(n=4-5)$. (F) Glucagon content in isolated islets from WT treated with vehicle and WT treated with rapamycin for 9 days ( $n=4$; presented as fold change from WT+Vehicle). (C) Glucagon secretion and $(\mathbf{H})$ islet glucagon content from isolated $\mathrm{WT}$ islets treated ex vivo with (30 nM) or without rapamycin ( $n=3-4$ mice/treatment). Data for $\mathbf{B}$ and $\mathbf{C}$ are shown as means \pm SEM. ${ }^{*} P \leq 0.05$ (1-way ANOVA with Dunnett's post-test). Data for $\mathbf{D}-\mathbf{H}$ are shown as means $\pm \mathrm{SEM}$. ${ }^{*} P \leq 0.05$ (Student's 2-tailed $t$ test). characterized by a nutritional shift from a fat-enriched maternal milk nutrition to a carbohydrate-rich diet. These results also suggest that mTORC1 in $\alpha$ cells might be important for nutrientinduced signals induced by a carbohydrate-rich diet after weaning. These results are consistent with evidence demonstrating that the weaning period plays a critical role in $\beta$ cell dynamics and function (30). Our morphological studies and analysis by flow cytometry during the first month of life suggest that $\alpha$ cell loss in $\alpha$ Raptor $^{\mathrm{KO}}$ mice after weaning resulted from decreased proliferation and enhanced apoptosis (Supplemental Figure 4, A-D). The role of autophagy in the $\alpha$ cell loss observed in $\alpha$ Raptor ${ }^{\mathrm{KO}}$ mice is unclear and future studies using genetic models or inhibitors of autophagy could be designed to answer this question. In contrast to $\alpha$ Raptor $^{\mathrm{KO}}$ mice, $\alpha$ Raptor ${ }^{\mathrm{HET}}$ mice also showed reduction in $\alpha$ cell mass only at 8 months, suggesting that long-term reduction of mTORC1 activity could have an impact on controlling $\alpha$ cell mass (Figure 3G). In summary, these studies showed that $\alpha$ cell dynamics are altered in $\alpha$ Raptor ${ }^{\mathrm{KO}}$ mice during the first month of life and suggest that mTORC1 is important for the transition from a developmental to a mature program in $\alpha$ cells and the nutrition shift associated with weaning.

The current studies show that the physiological role of $\alpha$ cell mTORC1 in the regulation of glucose homeostasis appears to be minor. In particular, hypoglucagonemia failed to decrease glucose levels after 12-hour fasting in $\alpha$ Raptor $^{\mathrm{KO}}$ mice (Figure 2D). Similar abnormalities in adaptation to fasting have been reported in other mouse models of near-total $\alpha$ cell ablation and low circulating glucagon levels $(18,31)$. These results are in marked contrast with the reduction in fasting glucose in mice with pharmacological or genetic inhibition of the glucagon receptor signaling (Gcgr-null), suggesting that low levels of glucagon in $\alpha$ Raptor ${ }^{\mathrm{KO}}$ mice are sufficient to mediate proper glucagon receptor signaling and maintain normoglycemia in the fasting state $(15,32)$. Interestingly, fasting blood glucose was higher in $\alpha$ Raptor ${ }^{\mathrm{KO}}$ mice than in control mice after 12 hours of fasting (Figure 2D). Higher gluconeogenesis, as shown by intraperitoneal pyruvate tolerance test, could contrib- 


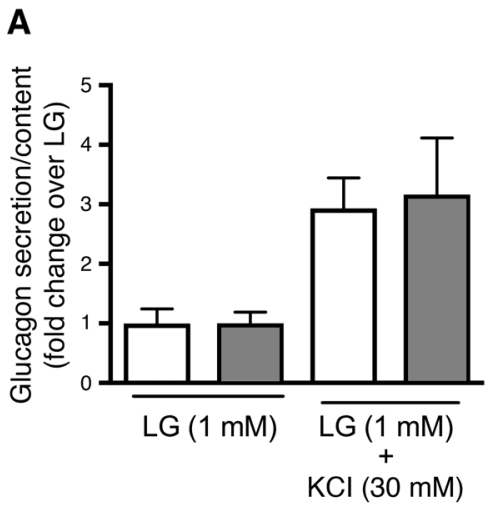

C

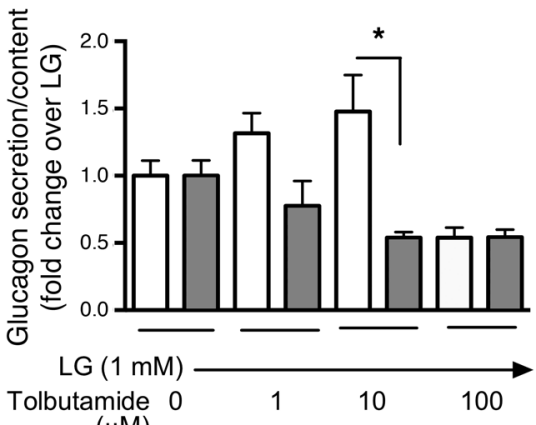

B

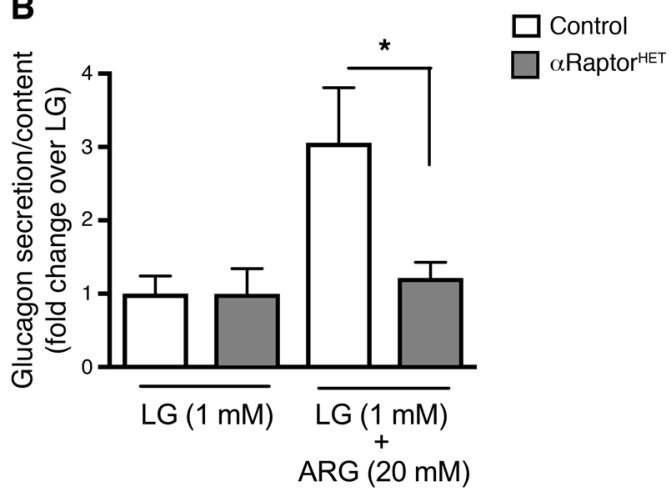

E

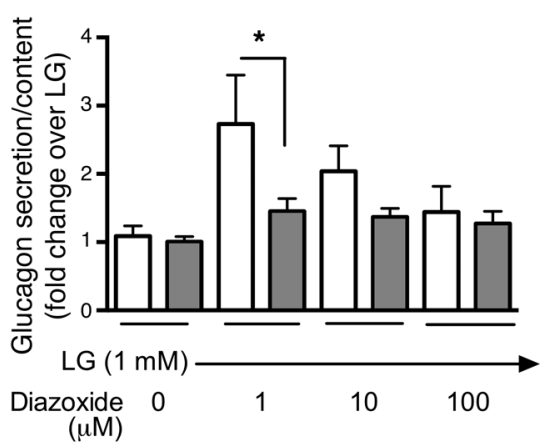

$\mathbf{F}$

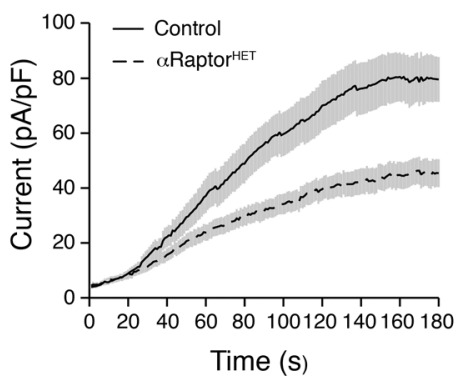

G

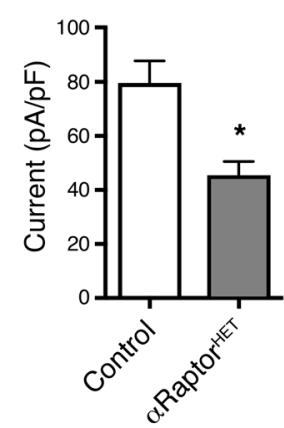

H

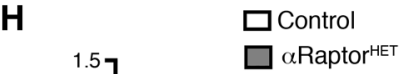

I

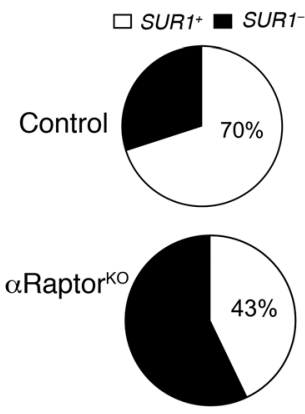

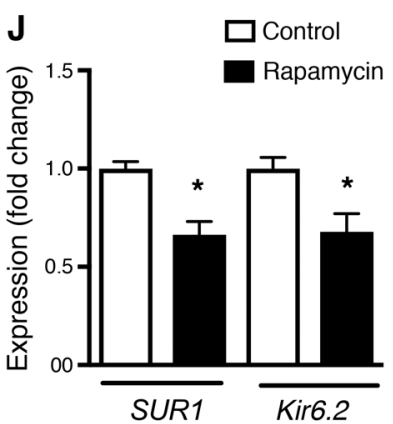

\section{K}

pS6 (S240/44)

SUR1

KIR6.2

Actin

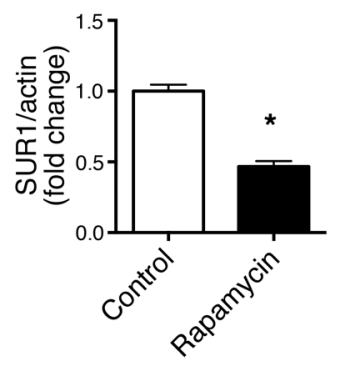

Ctrl Rapa Ctrl Rapa
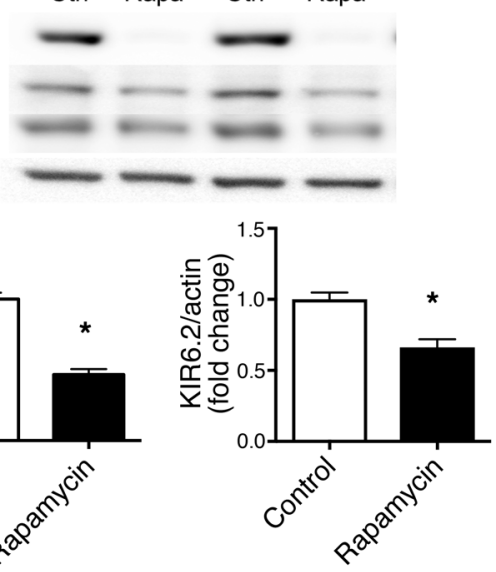

Figure 6. mTORC1 regulates glucagon secretion by alterations in $\mathrm{K}_{\mathrm{ATP}}$ channel expression and activity. Glucagon response from isolated islets to (A) $\mathrm{KCl}$ (30 $\mathrm{mM})(n=8$ mice $)$ and (B) arginine (ARG, $20 \mathrm{mM})(n=8$ mice) under low-glucose (LC, $1 \mathrm{mM}$ ) Krebs buffer. Glucagon response in isolated islets to increasing concentrations of $(\mathbf{C})$ tolbutamide $(0-100 \mu \mathrm{M})$ under low-glucose conditions ( $n=3-4$ mice), (D) diazoxide $(0-100 \mu \mathrm{M})$ under high-glucose ( $6 \mathrm{mM})$ conditions ( $n=5-8$ mice), and $(\mathbf{E})$ diazoxide $(0-100 \mu \mathrm{M})$ under low-glucose conditions ( $n=7-11$ mice). (F) $\mathrm{K}_{\text {ATP }}$ channel activity during washout of intracellular ATP and (G) current amplitude quantification at 180 seconds in $\alpha$ cells from control and $\alpha$ Raptor ${ }^{\text {HET }}$ mice ( $n=30-41$ cells from 3-4 mice). (H) RNA expression of SUR1 and Kir6. 2 in FACS-enriched $\alpha$ cell population from control and $\alpha$ Raptor ${ }^{\mathrm{HET}}$ mice $(n=6)$. (I) Single-cell analysis of SUR1 expression frequency in $\alpha$ cells from 1-month-old control and $\alpha$ Raptor ${ }^{\mathrm{K} 0}$ mice ( $n=20-21$ cells from 3-4 mice). (J) RNA expression ( $n=7-8)$ and (K) protein levels of SUR1 and KIR6.2 from $\alpha$ TC- 1 cells treated with vehicle or rapamy$\operatorname{cin}(30 \mathrm{nM})$ for 48 hours $(n=7)$. All secretion assays

(A-E) represent results from 2-3 independent experiments. Data are presented as fold change and shown as means \pm SEM. ${ }^{*} P \leq 0.05$ (Student's 2-tailed $t$ test). 
A

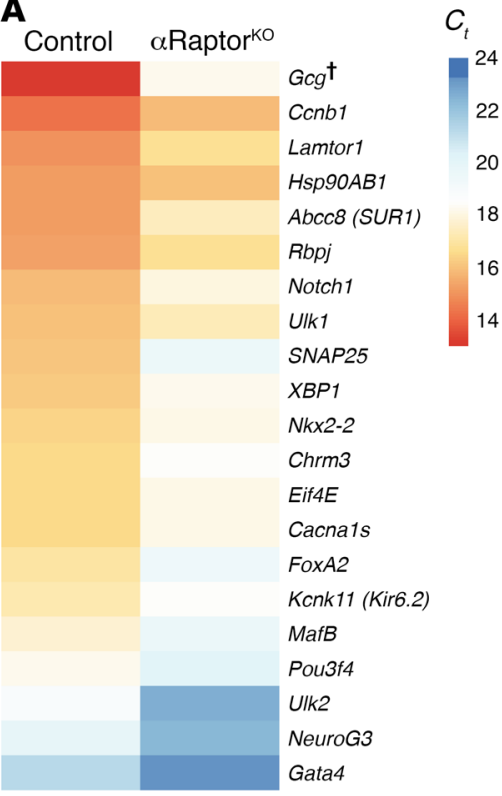

B
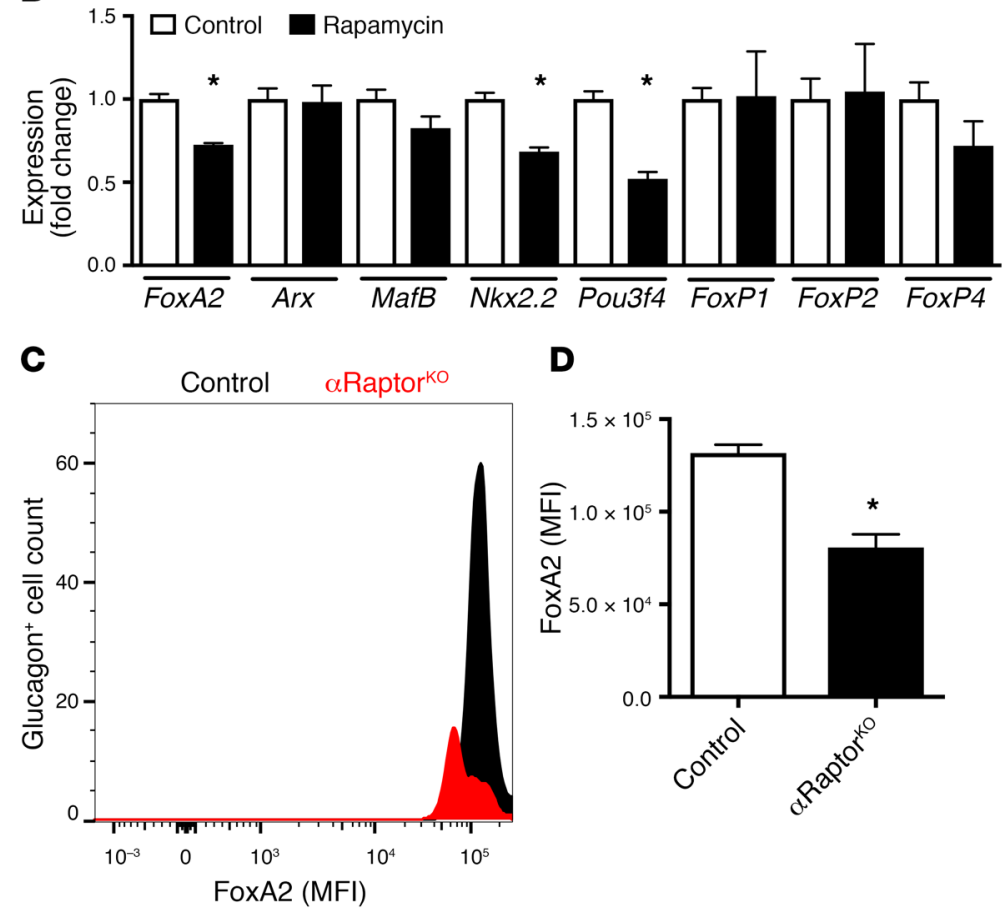

D

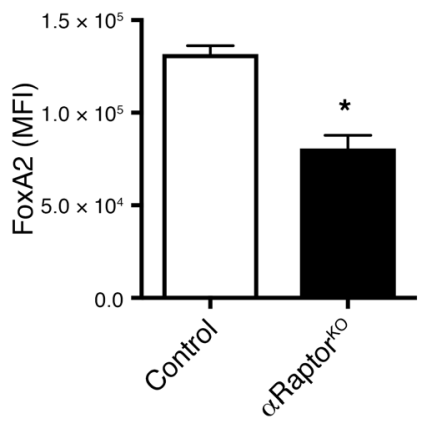

E

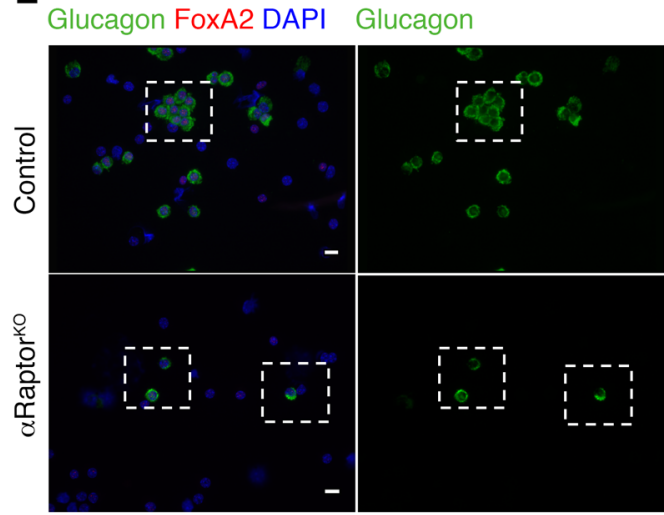

FoxA2

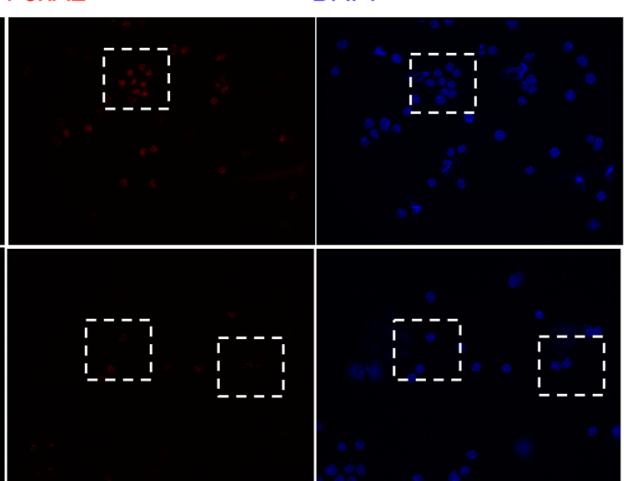

$\mathbf{F}$

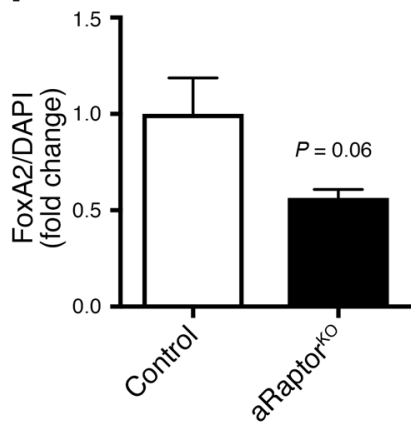

Figure 7. mTORC1 regulates the expression of genes involved in glucagon synthesis and regulation of glucagon secretion. (A) Heatmap represents mean Ct of differentially expressed genes $(P>0.05)$ from Fluidigm single-cell analysis of $\alpha$ cells from 3-week-old control and $\alpha$ Raptor ${ }^{\mathrm{K} 0}$ mice $(n=3-6$ mice) and (B) RNA expression of $\alpha$ cell transcription factors in $\alpha \mathrm{TC}-1$ cells treated with vehicle or rapamycin (30 nM) for 48 hours ( $n=4-8 /$ group). (C) FoxA2 protein expression and (D) quantification analysis by mean fluorescence intensity (MFI) in glucagon-positive cells from young control and $\alpha$ Raptor ${ }^{\mathrm{K} 0}$ mice $(n=3-4)$. (E) Immunofluorescence images representing FoxA2 (red), glucagon (green), and DAPI (blue) staining of isolated and dispersed islets from young control and $\alpha$ Raptorko mice. Scale bars: $10 \mu \mathrm{m}$. (F) Quantification of the ratio of the signal intensity of nuclear FaxA2 over DAPI in dispersed $\alpha$ cells from young control and $\alpha$ Raptor ${ }^{K 0}$ mice $(n=4$ mice). Data in A represent the mean C $t$ of differentially expressed genes $(P>0.05)$ in single cells by Student's 2 -tailed $t$ test and ${ }^{\dagger}$ MAST analysis. Data in B, D, and $\mathbf{F}$ are presented as fold change from control and shown as means \pm SEM. ${ }^{*} P \leq 0.05$ (Student's 2 -tailed $t$ test).

ute to explaining this finding. In addition, it is possible that there are compensatory increases in counterregulatory mechanisms, as demonstrated by responses to 2DG administration (Figure 4, $\mathrm{C}$ and D). In contrast to the lack of glucose abnormalities, glucagon levels in $\alpha$ Raptor $^{\mathrm{KO}}$ were decreased in the fed and fasting state (Figure 2, E and I). These changes could be explained by a marked reduction in $\alpha$ cell mass observed in $\alpha$ Raptor ${ }^{\mathrm{KO}}$, although it is possible that concomitant abnormalities in glucagon secretion can contribute (Figure 3, E and G). In contrast, $\alpha$ Raptor ${ }^{\mathrm{HET}}$ mice exhibited a reduction in circulating glucagon levels in the fed and fasting state and these changes were associated with normal $\alpha$ cell mass at 2 months (Figure $2 \mathrm{E}$ and Figure $3 \mathrm{E}$ ). Importantly, 2-month-old $\alpha$ Raptor ${ }^{\mathrm{HET}}$ mice also showed impaired glucagon secretion induced by insulin-induced hypoglycemia and glucoprivic conditions, suggesting that mTORC1 activity is important for glucagon secretion (Figure 2E and Figure 5, B and D). Ex vivo studies in isolated islets from $\alpha$ Raptor ${ }^{\mathrm{HET}}$ mice also support a role for mTORC1 inhibition in glucagon secretion (Figure 6, A-H). Finally, $\alpha$ Raptor ${ }^{\mathrm{KO}}$ and $\alpha$ Raptor ${ }^{\mathrm{HET}}$ mice showed reduced glucagon levels in response to fasting at 2 and 8 months of age (Figure 2, $\mathrm{E}$ and I). Although the mechanism for this finding is unclear, it is possible that this reflects defective glucagon secretion in response 
to the increase in circulating amino acids during the fasting state. Taken together, these studies are consistent with the concept that mTORC1 is required to maintain glucagon levels during fasting and in response to hypoglycemia. Interestingly, suppression of glucagon secretion in the fed state appears to not be regulated by the insulin/insulin receptor/mTORC1 axis.

The current studies demonstrate that reduction of mTORC1 signaling reduces glucagon secretion. The similar glucagon secretory responses to $\mathrm{KCl}$ treatment in controls and $\alpha \mathrm{Raptor}^{\mathrm{HET}}$ islets suggested that the events distal to calcium influx are conserved and the secretory defect occurred prior to cell depolarization (Figure 6A) (21). In contrast, glucagon responses to arginine, glutamine, or tolbutamide were impaired in $\alpha$ Raptor $^{\text {HET }}$ (Figure 6, B and C, and Supplemental Figure 5). While tolbutamide and arginine should also depolarize the $\alpha$ cell, KCl likely provided a much stronger depolarization that supports the sustained activation of L-type $\mathrm{Ca}^{2+}$ channels, as opposed to the P/Q-type channels that appear to control glucagon secretion under more physiologic conditions (33, 34). Based on these findings, together with impaired responses to low glucose observed in vivo, we hypothesized that the mechanistic defect in the glucagon secretory pathways in $\alpha$ Raptor ${ }^{\mathrm{HET}}$ lied at the level of the $\mathrm{K}_{\text {ATP }}$ channel. Therefore, we assessed glucagon secretion to pharmacologic agents that open or close $\mathrm{K}_{\mathrm{ATP}}$ channels in a dose-response manner (Figure 6, C-E) as described previously (23). The dose-response alterations to diazoxide and tolbutamide, $\mathrm{K}_{\text {ATP }}$ channel activity modulators, are consistent with reduced $\mathrm{K}_{\text {ATP }}$ channels and currents in $\alpha$ Raptor ${ }^{\mathrm{HET}} \alpha$ cells (Figure $6, \mathrm{~F}$ and $\mathrm{G}$ ). Titration of $\mathrm{K}_{\mathrm{ATP}}$ channel activity can enhance action potential firing to the point at which voltage-gated $\mathrm{Na}^{+}, \mathrm{Ca}^{2+}$, and $\mathrm{K}^{+}$channels undergo voltage-dependent inactivation (35-37) and thus suppress glucagon secretion (as seen with $100 \mu \mathrm{M}$ tolbutamide in the controls). The lower density of $\mathrm{K}_{\mathrm{ATP}}$ currents in the $\alpha$ Raptor ${ }^{\mathrm{HET}} \alpha$ cells is therefore consistent with the suppressive effect of tolbutamide on glucagon secretion occurring at low glucose concentrations, and the lack of effect of diazoxide. Interestingly, the increase in glucagon secretion by diazoxide in control islets is opposite to previously published data showing that a similar concentration of diazoxide inhibits, rather than stimulates glucagon secretion (33). The mechanisms for these differences are not completely clear but it is important to note that a fraction of $\mathrm{K}_{\text {ATP }}$ channels in $\alpha$ cells are open even at low glucose $(23,34)$. Therefore, it is still possible for diazoxide to open more $\mathrm{K}_{\mathrm{ATP}}$ channels at low glucose and have stimulatory rather than suppressive effects, depending on the fraction of open $\mathrm{K}_{\text {ATP }}$ channels at culture medium conditions used with low glucose. Expression studies demonstrated that the decrease in $\mathrm{K}_{\mathrm{ATP}}$ currents in $\alpha$ Raptor $^{\mathrm{HET}} \alpha$ cells resulted in part from lower Kir6.2 and SUR1 mRNA expression in $\alpha$ Raptor ${ }^{\mathrm{HET}}$ mice, indicating that mTORC1 signaling controls transcription of $\mathrm{K}_{\text {ATP }}$ channel components (Figure 6, F-H). Reductions in SUR1 and Kir6.2 mRNA expression were validated in single $\alpha$ cell expression analysis in $\alpha$ Raptor $^{\mathrm{KO}}$ (Figure 6I, Figure 7A, and Table 1) and reductions in SUR1 and KIR6.2 protein and mRNA levels were validated in $\alpha$ TC- 1 cells treated with rapamycin (Figure 6, J and K). Glucagon secretion induced by different secretagogues was reduced by acute treatment of wild-type islets with rapamycin, suggesting that mTORC1 could also modulate glucagon secretion by controlling $\mathrm{K}_{\text {ATP }}$ channel activity, although the precise mechanism is unclear
(Figure 5, G and H). Finally, decreased expression of several genes involved in secretory machinery (SNAP25, Chrm3, Cacna1s) in $\alpha$ Raptor $^{\mathrm{KO}}$ mice indicates that additional mechanisms could also be involved (Figure 7A and Table 1). Taken together, these results uncovered a previously unknown function of mTORC1 signaling in controlling glucagon secretion by modulating $\mathrm{K}_{\text {ATP }}$ channel activity and expression of $\mathrm{K}_{\mathrm{ATP}}$ channel subunits as well as genes of the secretory machinery.

Our data showed that inhibiting mTORC1 signaling in $\alpha$ Raptor $^{\mathrm{KO}}$ mice and chronic rapamycin administration in vivo leads to decreased glucagon content and glucagon secretion. Single-cell gene expression analysis further showed that the decreased glucagon content resulted from reduced glucagon $(G c g)$ gene expression in $\alpha$ Raptor ${ }^{\mathrm{KO}}$ and key transcription factors important for $\alpha$ cell development, maintenance, and glucagon synthesis including FoxA2, Neoreg3, Gata4, MafB, Pou3f4, and Nkx2.2 (Figure 7A and Table 1) (38-41). The changes in FoxA2 were particularly interesting, as this transcription factor has been shown to play a major role in regulating $G c g, S U R 1$, and Kir6.2 expression (25-29). FoxA2 protein levels and nuclear FoxA2 levels were also significantly reduced in $\alpha$ cells from young $\alpha$ Raptor $^{\mathrm{KO}}$ mice (Figure 7, C-F). The decrease in FoxA2 gene transcription in $\alpha$ Raptor ${ }^{\mathrm{KO}}$ mice together with published data linking FoxA2 to Gcg, SUR1, and Kir6.2 transcription suggest that reduction in FoxA2 could be the link between mTORC1 and Gcg, SUR1, and Kir6.2 transcription in $\alpha$ Raptor ${ }^{\mathrm{KO}}$ mice. A decrease in the FoxA2 targets MafB, Pou3f4, and $N k x 2.2$, also supports the concept that FoxA2-dependent transcription was reduced in $\alpha$ Raptor $^{\mathrm{KO}}$ mice (26). Overall, our data identified mTORC1 as a potentially novel regulator of FoxA2 and suggest that this transcription factor links nutrient signaling to transcriptional regulation in $\alpha$ cells.

In summary, dysregulation of glucagon secretion plays a major pathogenic role in the development of hyperglycemia in T2D and failure to secrete glucagon in T1D or advanced T2D patients results in recurrent hypoglycemia. These studies provide potentially novel insights into the molecular mechanisms and signaling pathways regulating glucagon secretion and $\alpha$ cell mass. Our findings identify mTORC1 as a major signaling pathway controlling glucagon secretion under states of low glucose and identify a potentially novel mechanistic link between mTORC1/FoxA2 in transcriptional regulation in $\alpha$ cells. These alterations were recapitulated by treatment with the immunosuppressant rapamycin, a known mTORC1 inhibitor used in the clinic. The findings obtained by rapamycin treatment could have major clinical implications in responses to hypoglycemia in posttransplant diabetics and perhaps explain the defects in counterregulation of hypoglycemia in patients after islet transplantation under chronic immunosuppression by rapamycin analogs $(42,43)$.

\section{Methods}

Animals. Mice were housed in a pathogen-free environment and maintained on 12-hour light/dark cycle at the University of Michigan Brehm Center Animal Facility. The glucagon-Cre mice (gift from George K. Gittes at the University of Pittsburgh, Pittsburgh, Pennsylvania, USA), express Cre recombinase driven by the glucagon promoter (18). These mice were crossed with Raptor ${ }^{f / f l}$ (gift from Michael N. Hall and Markus A. Rüegg at the University of Basel, Basel, Switzerland) (19). 
We generated 3 experimental groups for all described experiments: controls (Raptor ${ }^{f / f l}$, Raptor $^{f /+}$, and glucagon-Cre), $\alpha$ Raptor $^{\mathrm{KO}}$ (glucagonCre; Raptor ${ }^{f l f f}$ ), and $\alpha$ Raptor $^{\mathrm{HET}}$ (glucagon-Cre; Raptor ${ }^{f /+}$ ). All animals were born in expected mendelian ratios and expected lifespans. Reporter transgenic animals CAG-tdTomato, Ins1-EGFP and CAG-YFP were purchased from The Jackson Laboratory. Reporter transgenic mice, GFP-LC3 (RBRC number RBRC00806) were obtained from RIKEN with the permission of the depositor (Noboru Mizushima, The University of Tokyo, Tokyo, Japan) (20). All metabolic (2 or 8 months) and ex vivo islet secretion (2 months) studies were performed with aged-matched male mice. Islet morphometric analysis utilized agematched cohorts with male and female mice.

Metabolic studies. Body weight and random blood glucose were monitored monthly for a total of 4 months. Fed (9 AM) and fasting (12 hours; 9 PM) glucose, insulin, and glucagon levels were evaluated in 2- and 8-month-old males. Blood was obtained from the tail vein and blood glucose was measured with an Accu-Chek blood glucose meter. Glucagon and insulin levels were measured with ELISAs (Mercodia [25 $\mu \mathrm{l}$ assay] and Alpco, respectively). Active GLP-1 levels in plasma and intestinal tissue were measured by STELLUX Chemi Ultrasensitive Active GLP-1 ELISA (7-36) amide (25 $\mu$ l assay with a sensitivity of $<0.1 \mathrm{pM})$. Intraperitoneal glucose tolerance test (IPGTT) $(2 \mathrm{~g} /$ $\mathrm{kg})$, insulin tolerance test (ITT) $(1 \mathrm{U} / \mathrm{kg})$, and 2DG $(150 \mathrm{mg} / \mathrm{kg})$ were performed by intraperitoneal injections of respective agents in 4- to 6-hour-fasted male mice (44). Hepatic glucose production was measured by intraperitoneal injection of pyruvate $(2 \mathrm{~g} / \mathrm{kg})$ in 16-hourfasted male mice.

Hormone content analysis in tissue extracts. To measure pancreatic glucagon content and intestinal active GLP-1 content, we dissected and measured the weight of the pancreas and total intestine (intestine was cleaned prior to processing). The tissues were homogenized in acid-ethanol $(3 \mathrm{ml})$ and incubated with gentle rotation at $4^{\circ} \mathrm{C}$ for 72 hours. The tissue homogenate was centrifuged and glucagon or active GLP-1 level was measured in the collected supernatant (R\&D Systems Duoset Glucagon Elisa and STELLUX Chemi Ultrasensitive Active GLP-1 ELISA 7-36). The hormone content measure takes into account the tissue weight and the final volume of supernatant collected (hormone concentration multiplied by tissue weight and divided by the volume of supernatant from tissue extract). Liver glycogen content was measured with a Glycogen Assay Kit (Sigma-Aldrich) following the manufacturer's instructions.

Preparation and in vivo treatment with agents. Rapamycin (LC Laboratories) was dissolved in $100 \%$ ethanol and stored at $-20^{\circ} \mathrm{C}$. The stock solution was further diluted in an aqueous solution of $5.2 \%$ Tween 80 and 5.2\% PEG 400 with a final concentration of ethanol of $2 \%(45,46)$. Wild-type mice were injected with rapamycin $(2 \mathrm{mg} /$ $\mathrm{kg}$ ) every other day for 9 days. ITT was performed on day 8 between injections. Necropsy was performed on day 9 after the last injection.

Immunofluorescence and cell morphometry. Pancreata were fixed in $3.7 \%$ formaldehyde, embedded in paraffin and sectioned $(5 \mu \mathrm{m})$. Fluorescence images were acquired using a microscope (Leica DM5500B) and a motorized stage using a camera (Leica DFC360FX) (Leica Microsystems). Cell mass was determined in 5 stained sections (5 $\mu \mathrm{m})$ separated by $200 \mu \mathrm{m}$ as previously described $(47,48)$. The area of insulin, glucagon, somatostatin, and pancreatic polypeptide and the area of each section were quantified with Image Pro Software (version 7; Media Cybernetics). The ratio of the 5 hormone-stained areas to the total pancreatic section area for each mouse were averaged and multiplied by the pancreas weight.

Dispersed cell staining was performed by gently dispersing isolated islets with trypsin-EDTA (0.25\% trypsin, $1 \mathrm{mM}$ EDTA). The cells were cytofuged using a StatSpin Cytofuge 2 (Beckman Coulter) on slides pre-coated with poly-L-lysine. The cells were immediately fixed with $3.7 \%$ formaldehyde for 20 minutes and incubated with Trisbuffered saline containing $0.1 \%$ Triton for 10 minutes at room temperature. For FoxA2 staining, the cells were additionally permeabilized with cold methanol at $4^{\circ} \mathrm{C}$ for 10 minutes (after fixation with formaldehyde). Analysis of nuclear FoxA2 and DAPI signal intensity was done on 16-bit images acquired at $\times 40$ magnification. FoxA2 and DAPI levels were determined my measuring pixel intensity using Adobe Photoshop (Adobe Systems). Assessment of cell death was measured by immunofluorescence-based apoptosis TUNEL assay (Millipore) in 3-5 stained sections $(5 \mu \mathrm{m})$ separated by $200 \mu \mathrm{m}$ and costained for glucagon and DAPI. Assessment of cell proliferation was measured by staining and counting $\mathrm{Ki}^{+} / \mathrm{glucagon}^{+}$cells (Sigma-Aldrich) in 3-5 stained sections $(5 \mu \mathrm{m})$ separated by $200 \mu \mathrm{m}$ and costained for glucagon and DAPI. Cell size was calculated by immunofluorescent staining of dispersed islets from 1-month-old mice for glucagon and DAPI and measuring the area of glucagon-positive cells using NIH ImageJ software (v1/49d available at http://rsb.info.nih.gov/ij/index. html). Assessment of Cre-mediated recombination was measured by counting the number of glucagon ${ }^{+} /$reporter $^{+}$cells in dispersed islets from Glucagon-Cre ${ }^{\mathrm{YFP}}$ and Glucagon-Cre ${ }^{\text {tdTomato }}$ mice (2 months old). Assessment of autophagy was assessed in control and $\alpha$ Raptor ${ }^{\mathrm{KO}}$ mice bred to GFP-LC3 mice (20). Islets from 1-month-old Control ${ }^{\text {GFP-LC3 }}$ and $\alpha$ Raptor ${ }^{\mathrm{KO} ; G \mathrm{GP}-\mathrm{LC} 3}$ mice were isolated, dispersed, and cytofuged on slides and stained for glucagon, GFP, and DAPI. All antibodies used are summarized in Supplemental Table 1.

Flow cytometry. Islets were isolated and incubated overnight in RPMI containing $5 \mathrm{mM}$ glucose. The islets were dispersed into a singlecell suspension and fixed with a BD Pharmingen Transcription Factor Phospho Buffer Set (BD Biosciences). The fixed cells were incubated with conjugated antibodies overnight, at $4^{\circ} \mathrm{C}$ and with gentle rotation. Dead cells were excluded by Ghost Dye Red 780 (Tonbo). Glucagon, insulin, FoxA2, LC3, Ki67, annexin V, and pS6 (Ser240) expression was analyzed by MFI (a measure of protein expression or posttranslational modification) per glucagon-positive cell using a BD LSR II (BD Biosciences). The size of live glucagon-positive cells was analyzed by forward scatter area (FSC-A) and glucagon MFI. All antibodies used are summarized in Supplemental Table 1.

Fluorescence-activated cell sorting (FACS). Control (glucagon$\mathrm{Cre}$ ) and $\alpha$ Raptor ${ }^{\mathrm{HET}}$ mice were crossed to reporter mice Ins1EGFP and CAG-tdTomato. The islets from 2-month-old Glucagon$\mathrm{Cre}^{\text {Ins1GFP;tdTomato }}$ and $\alpha$ Raptor $^{\text {HET;Ins1-EGFP;tdTomato }}$ were isolated and incubated overnight in RPMI containing $5 \mathrm{mM}$ glucose. The islets were dispersed into a single-cell suspension. Sorting was performed on a FACS Aria III (BD Biosciences) at the University of Michigan and Moflo Astrios EQ (Beckman Coulter) at the University of Miami. Dead cells were excluded with DAPI (Sigma-Aldrich) or Ghost Dye Red 780. Cells expressing CAG-tdTomato (glucagon and insulin) and cells expressing Ins1-EGFP (all insulin) were sorted in separate collection tubes, representing the Tomato gate and GFP gate, respectively. Hormone content in each gate was analyzed in 4 control animals by ELISAs for glucagon (Duoset, R\&D Systems) and insulin (Alpco) and 
normalized to the number of cells sorted. The $\beta$ cell content in different islet batches was consistently around $30 \%$ among the different FACS experiments (Supplemental Figure 4). Assessment of viability after sorting in young Glucagon-Cre ${ }^{\text {Ins1GFP;tdTomato }}$ and $\alpha$ Raptor ${ }^{\text {KO;Ins1-EGFP;tdTomato }}$ mice showed similar viability between control and $\alpha$ Raptor ${ }^{\mathrm{KO}}$ mice (87\%-98\% postsorting viability).

$K_{\text {ATP }}$ channel activity. Islets from Glucagon-Cre $\mathrm{t}^{\text {tdTomato }}$ and $\alpha$ Raptor ${ }^{\text {HET;tdTomato }}$ mice, expressing a fluorescent reporter in $\alpha$ cells, were dispersed to single cells and plated overnight on $35-\mathrm{mm}$ dishes as described previously (49). Cells were patch-clamped in the wholecell voltage-clamp configuration in a heated bath at $32^{\circ} \mathrm{C}-35^{\circ} \mathrm{C}$ using a HEKA EPC10 amplifier and PatchMaster Software (Heka Electronik) and patch pipettes with resistances of 5-6 MOhm after fire polishing. Whole-cell currents of $\mathrm{K}_{\text {ATP }}$ channels were recorded in response to voltage steps going to -60 and $-80 \mathrm{mV}$ from a holding potential of -70 $\mathrm{mV}$. For the $\mathrm{K}_{\text {ATP }}$ current measurement, the bath solution contained 138 $\mathrm{mM} \mathrm{NaCl}, 5.6 \mathrm{mM} \mathrm{KCl}, 1.2 \mathrm{mM} \mathrm{MgCl}, 2.6 \mathrm{mM} \mathrm{CaCl}_{2}, 5 \mathrm{mM}$ HEPES, and $1 \mathrm{mM}$ glucose ( $\mathrm{pH}$ 7.4). The pipette solution for these experiments contained $125 \mathrm{mM} \mathrm{KCl}, 30 \mathrm{mM} \mathrm{KOH}, 1 \mathrm{mM} \mathrm{MgCl}, 10 \mathrm{mM}$ EGTA, 5 mM HEPES, 0.3 mM Mg-ATP, and 0.3 mM K-ADP (pH 7.15). Following the experiments, $\alpha$ cells were positively identified by immunostaining for glucagon (guinea pig anti-glucagon, 1:5,000; Linco), and appropriate secondary antibody (Alexa Fluor 594 goat anti-guinea pig, 1:200; Invitrogen). Data were analyzed using FitMaster (Heka Electronik).

Islet studies. Islet isolation was accomplished by collagenase digestion as described previously (47). Glucagon secretion ex vivo was assessed by static incubation using isolated islets. Briefly, after overnight culture in RPMI containing $5 \mathrm{mM}$ glucose, islets were precultured in Krebs-Ringer (KRBB) medium containing $6 \mathrm{mM}$ glucose and $0.2 \%$ BSA for 1 hour. Groups of 15 islets/mouse were placed in $8-\mu \mathrm{m}$ cell culture inserts (Millicell), preincubated in high-glucose (HG) KRBB $(6 \mathrm{mM}$ glucose) for 1-2 hours and incubated subsequently for 1 hour in each of the following conditions: low-glucose (LG) KRBB (1 mM glucose, with a brief wash with LG between HG KRBB and LG KRBB) and LG KRBB plus arginine $(20 \mathrm{mM})$ or $\mathrm{KCl}(30 \mathrm{mM})$. Dose-response experiments measuring glucagon response to diazoxide and tolbutamide were performed using a 30-minute exposure per condition. Glucagon response after acute rapamycin treatment was performed in wild-type islets incubated with $30 \mathrm{nM}$ rapamycin for 30 minutes under increasing glucose concentrations from $1 \mathrm{mM}$ to $24 \mathrm{mM}$ for a total duration of 2 hours under rapamycin treatment. Glucagon response to glutamine and rapamycin (30 $\mathrm{nM}$ ) was performed after a 30-minute incubation in KRBB containing $4 \mathrm{mM}$ glucose and increasing glutamine concentrations (1, 3 , and $5 \mathrm{mM}$ ) every 30 minutes for a total duration of 2 hours under rapamycin treatment. Assessment of glucagon content in islets was performed by acid-ethanol extraction using 15 islets per condition. All assays represent results from 2-3 independent experiments. Secreted glucagon levels and islet glucagon content were measured using Glucagon Duoset ELISA. All glucagon secretion data were normalized to the islet glucagon content and presented as fold change.

Single-cell RT-PCR. The following methods were adapted and modified from Liss et al. and Shiota et al. (21, 50). Red-fluorescent $\alpha$ cells from dispersed islets obtained from 1-month-old Control ${ }^{\text {tdTomato }}$ and $\alpha$ Raptor ${ }^{\mathrm{KO} ; \mathrm{td} T o m a t o}$ were individually hand-picked under an inverted phase-contrast microscope (Leica DMI 3000B). Each cell was collected with a pipette adjusted to $1.5 \mu \mathrm{l}$ in individual tubes with $3.5 \mu \mathrm{l}$ water and $5 \mu \mathrm{l}$ of a mix containing $1 \mu \mathrm{l} 10 \times \mathrm{RT}$ Buffer (Applied Bio- systems), $0.5 \mu$ l RNAse inhibitor (10 Units; Applied Biosystems), and $0.5 \mu$ dithiothreitol (10 mM; DTT). Following snap freezing on dry ice, cell lysates were subjected to first-strand cDNA synthesis by using a High-Capacity Reverse Transcription cDNA Kit following the manufacturer's directions (Applied Biosystems). Each cell was treated as separate reaction yielding a final volume of $20 \mu$ l. Reverse transcription (RT) reactions were carried out for 60 minutes at $42^{\circ} \mathrm{C}$, followed by incubation at $75^{\circ} \mathrm{C}$ for 15 minutes. All cells underwent quantitative PCR amplification for glucagon and $18 S$. Only confirmed glucagonpositive cells were included in the analysis.

Single-cell nested RT-PCR for SUR1 and raptor. For SUR1, cDNA from single cells obtained as described above was subjected to a first round of RT-PCR using $8 \mu \mathrm{l}$ of RT reaction, outside SUR1 primers $(0.5 \mu \mathrm{M})$, $\mathrm{MgCl}_{2}(2 \mathrm{mM})$, dNTPs $(0.4 \mathrm{mM})$, and 2 Units Platinium Taq (Invitrogen), in a total volume of $20 \mu$. The first RT-PCR was performed under the following conditions: 3 minutes at $94^{\circ} \mathrm{C}, 35$ cycles $\left(94^{\circ} \mathrm{C}\right.$ for $30 \mathrm{sec}-$ onds, $58^{\circ} \mathrm{C}$ for 60 seconds, $72^{\circ} \mathrm{C}$ for 3 minutes), and final elongation at $72^{\circ} \mathrm{C}$ for 7 minutes using a MasterCycler pro S (Eppendorf). The product of the reaction was used as template for a second round of PCR using $1 \mu \mathrm{l}$ of first-PCR product template and $19 \mu \mathrm{l}$ of a mix containing Power SYBR Green PCR Mix (Applied Biosystems), inside primers and water, and was performed using StepOnePlus detection system (Applied Biosystems). The final product for SUR1 was visualized in an ethidium bromide-stained agarose gel (2\%) by electrophoresis. The results were analyzed by the presence or absence of a positive band. Positive (whole islets) and negative (water) controls were used in every experiment. Primers were purchased from IDT. All primer sequences are available in Supplemental Table 2. Confirmation of Raptor deletion was performed by nested RT-PCR of exon 6 (flanked exon) using cDNA obtained from single cells as described above. The first round of amplification was performed with outside primers (exon 5 and exon 7; Supplemental Table 2). The product of this reaction was used as a template for a second round of amplification using exon 6-specific primers (Supplemental Table 2). See complete unedited gels in the supplemental material.

Single-cell analysis by Fluidigm. Islets from 3-week-old control (Raptor $\mathrm{f} / \mathrm{f}^{\text {Ins1-GFP;tdTomato }}$ and Ins1-GFP; tdTomato $(n=6)$ and

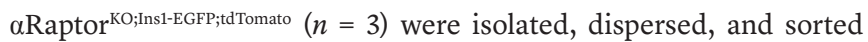
based on GFP ( $\beta$ cells), RFP ( $\alpha$ cells), and viability to enrich an $\alpha$ cell population. The viability (87\%-97\%) and concentration (250-300 cells/ $\mu \mathrm{l})$ of cells were measured using a Countess Automated Cell Counter and mixed with C1 Cell Suspension Reagent (Fluidigm) in a 3:2 ratio. The cells were captured into a small-sized $(5-10 \mu \mathrm{m})$ or middle-sized (10-17 $\mu \mathrm{m})$ integrated fluidic circuit (IFC) before undergoing cell lysis, reverse transcription, and cDNA amplification in the C1 Single-Cell Auto Prep instrument. Capture sites containing a single cell were identified by careful examination of the IFC using an Olympus CK2 inverted microscope. Quantitative RT-PCR of 96 Delta iGene Assays was performed by BiomarkHD (Fluidigm) using pre-amplified cDNA from single cells, positive (bulk cell), and negative (no template) controls from each IFC capture. Glucagon ${ }^{+}$cells were identified as single cells with detectable levels of $G c g$ gene expression in the Biomark HD data (Control $n=10$, $\alpha$ Raptor ${ }^{\mathrm{KO}} n=19$ cells). Delta Gene Assays were validated for single-cell gene expression analysis on a Biomark HD using mouse pancreatic total islet mRNA serially diluted over 12 two-fold dilutions (512 pg to $0.25 \mathrm{pg}$ ) and 7 replicates.

Quantitative real-time PCR. For mRNA expression of $\alpha \mathrm{TC}-1$ and islets, total RNA was extracted using the RNeasy isolation kit (Qiagen). 
Gene expression was assessed by quantitative real-time RT-PCR using Power SYBR Green PCR Mix (Applied Biosystems) on a StepOnePlus detection system (Applied Biosystems) with a standard protocol including a melting curve. Relative abundance for each transcript was calculated by a standard curve of cycle thresholds and normalized to $18 \mathrm{~S}$ ( $\alpha$ TC- 1$)$ and $\beta$-actin (islets). Primers were purchased from IDT, with the exception of Arx1, MafB, and Nkx2.2, which were purchased from Operon. All primer sequences are available in Supplemental Table 2.

Cell culture studies. $\alpha \mathrm{TC}-1$ cells clone 6 were purchased from ATCC Cell Lines and maintained according to the company's instructions. For rapamycin experiments, the cells were cultured in 12-well plates and incubated in complete media with vehicle control or rapamycin (30 nM) for 48 hours.

Western blotting. $\alpha \mathrm{TC}-1$ cells were collected and lysed in lysis buffer (125 mM Tris, pH 7; 2\% SDS, 1 mM DTT) containing phosphatase (Roche Diagnostics) and protease (Sigma-Aldrich) inhibitor cocktails. Cell lysates were boiled for 10 minutes, loaded, and electrophoresed in $12 \%$ SDS-PAGE and transferred to polyvinylidene fluoride membranes. All antibodies used are listed in Supplemental Table 1. Images were acquired using a Western Bright Sirius kit (BioExpress). Band densitometry was performed by measuring pixel intensity using $\mathrm{NIH}$ Image J software and normalized to actin in the same membrane. Detection of SUR1 was accomplished using an anti-SUR1 antibody (gift from Show-Ling Shyng, Oregon Health \& Science University, Portland, Oregon, USA). See complete unedited blots in the supplemental material.

Electron microscopy. Islets were isolated and fixed with $2 \%$ glutaraldehyde overnight at $4^{\circ} \mathrm{C}$, dehydrated, and embedded in Epon by the Microscopy \& Image Analysis Laboratory Core (MiCores, University of Michigan). Ultrathin sections were stained with uranyl acetate and lead citrate. Images were recorded digitally using an electron microscope (JEM-1400 Plus).

Statistics. Assessment of the normality of the data by D'AgostinoPearson (omnibus K2) supported the use of parametric statistical tests. The statistical analysis for comparisons between 2 groups was performed by unpaired (2-tailed) Student's $t$ test. One-way ANOVA with post-hoc Dunnett's multiple comparisons test was used for comparisons among 3 or more groups over several time points (GraphPad Prism). $P$ values less than or equal to 0.05 were considered significant. Analysis of Fluidigm single-cell data identified 55 gene assays (Supplemental Table 3) that qualified for statistical analysis by 2-tailed Student's $t$ test ( $\geq 3$ data points/group). Principle component analysis (PCA) was performed using gene expression from 55 genes to evaluate whether the groups were separated distinctively. The heatmap represents the mean $C t$ of differentially expressed genes $(P>0.05$; absolute fold change $>1.5$ ) from 2-tailed Student's $t$-test analysis. We applied a second method of statistical analysis to the data set using R-based MAST (model-based analysis of single-cell transcriptomics) package
(51). The $G c g$ gene was identified as significantly different between the groups using MAST analysis.

Study approval. All protocols were approved by the University of Michigan and the University of Miami Animal Care and Use Committees and were in accordance with NIH guidelines.

\section{Author contributions}

NB designed and performed the experiments, analyzed results and wrote the manuscript. EBM conceived and designed experiments, analyzed results, and wrote the manuscript. NB, XQD, JC, KC, JG, and MBR performed experiments and analyzed results. GKG, MAR, and $\mathrm{MNH}$ generated mice. PEM designed and performed $\mathrm{K}_{\mathrm{ATP}}$ channel activity experiments, analyzed results, and contributed to the writing and discussion of the manuscript. DD, ACP, and all other authors contributed to discussion and reviewed/edited the manuscript.

\section{Acknowledgments}

The authors wish to acknowledge funding resources for this essential contribution to this work. E.B.M. is mainly supported by a MERIT award from the Veterans Administration. This work was supported in part by Merit Review Award IBX002728A from the U.S. Department of Veterans Affairs Biomedical Laboratory Research and Development Program. Additional funding includes NIH grants R01-DK073716 and DK084236. N.B. was supported by NIH grant T-32-GM007315 and a Rackham Merit Fellowship (University of Michigan). J.C. was supported by NIH grants T-32GM007315 and HD007505. The work in the A.C.P. group is supported by grants from the Juvenile Diabetes Research Foundation (JDRF) (grants 5-2011-379 and 2-SRA-2016-149), Department of Veterans Affairs (BX000666), the NIH (DK89572, DK104211, DK106755), and the Vanderbilt Diabetes Research and Training Center (DK020593). D.D. was supported by a Vanderbilt Molecular Endocrinology Training Program grant (5T32 DK07563) and a JDRF Postdoctoral Fellowship Award. We acknowledge support from the Morphology and Image Analysis Core, Metabolomics Core and Phenotyping Core from the Michigan Diabetes Research Center (MDRC) (P30 DK020572). We would like to acknowledge Oliver Umland at the Flow Cytometry Core Facility (Diabetes Research Institute; University of Miami) and Lesley De Armas and Li Pan (CFAR; University of Miami; NIH P30AI073961). We thank Charles Burant, Ken Inoki, John Williams, and Lei Yin (University of Michigan) for discussion of the data.

Address correspondence to: Ernesto Bernal-Mizrachi, Department of Internal Medicine, Division of Endocrinology, Diabetes and Metabolism University of Miami, Miller School of Medicine and Miami VA Health Care System, Miami, Florida 33136, USA. Phone: 305.243.5631; Email: ebernalm@med.miami.edu.

\footnotetext{
1. Dinneen S, Alzaid A, Turk D, Rizza R. Failure of glucagon suppression contributes to postprandial hyperglycaemia in IDDM. Diabetologia. 1995;38(3):337-343.

2. Sherwin RS, Fisher M, Hendler R, Felig P. Hyperglucagonemia and blood glucose regulation in normal, obese and diabetic subjects. N EnglJ Med.1976;294(9):455-461.

3. Mezza T, et al. Insulin resistance alters islet
}

morphology in nondiabetic humans. Diabetes. 2014;63(3):994-1007.

4. Cryer PE. Hypoglycaemia: the limiting factor in the glycaemic management of Type I and Type II diabetes. Diabetologia. 2002;45(7):937-948.

5. Gerich JE, Langlois M, Noacco C, Karam JH, Forsham PH. Lack of glucagon response to hypoglycemia in diabetes: evidence for an intrinsic pancreatic alpha cell defect. Science.
1973;182(4108):171-173.

6. Segel SA, Paramore DS, Cryer PE. Hypoglycemiaassociated autonomic failure in advanced type 2 diabetes. Diabetes. 2002;51(3):724-733.

7. Kawamori D, et al. Insulin signaling in alpha cells modulates glucagon secretion in vivo. Cell Metab. 2009;9(4):350-361.

8. Cantley J, et al. Pancreatic deletion of insulin receptor substrate 2 reduces beta and alpha cell 
mass and impairs glucose homeostasis in mice. Diabetologia. 2007;50(6):1248-1256.

9. $\mathrm{Xu} \mathrm{E}$, et al. Intra-islet insulin suppresses glucagon release via GABA-GABAA receptor system. Cell Metab. 2006;3(1):47-58.

10. Schinner S, et al. Protein kinase B activity is sufficient to mimic the effect of insulin on glucagon gene transcription. J Biol Chem. 2005;280(8):7369-7376.

11. Liu $Z$, et al. Insulin and glucagon regulate pancreatic $\alpha$-cell proliferation. PLOS ONE. 2011;6(1):e16096.

12. Solloway MJ, et al. Glucagon couples hepatic amino acid catabolism to mTOR-dependent regulation of $\alpha$-cell mass. Cell Rep. 2015;12(3):495-510.

13. Pipeleers DG, Schuit FC, Van Schravendijk CF, Van de Winkel M. Interplay of nutrients and hormones in the regulation of glucagon release. Endocrinology. 1985;117(3):817-823.

14. Yang J, et al. Polyomic profiling reveals significant hepatic metabolic alterations in glucagon-receptor (GCGR) knockout mice: implications on antiglucagon therapies for diabetes. BMC Genomics. 2011;12:281.

15. Longuet $\mathrm{C}$, et al. Liver-specific disruption of the murine glucagon receptor produces $\alpha$-cell hyperplasia: evidence for a circulating $\alpha$-cell growth factor. Diabetes. 2013;62(4):1196-1205.

16. Dean ED, et al. Interrupted glucagon signaling reveals hepatic $\alpha$ cell axis and role for L-glutamine in $\alpha$ cell proliferation. Cell Metab. 2017;25(6):1362-1373.e5.

17. Kim J, et al. Amino acid transporter Slc38a5 controls glucagon receptor inhibition-induced pancreatic $\alpha$ cell hyperplasia in mice. Cell Metab . 2017;25(6):1348-1361.e8.

18. Shiota $C$, et al. $\alpha$-Cells are dispensable in postnatal morphogenesis and maturation of mouse pancreatic islets. Am J Physiol Endocrinol Metab. 2013;305(8):E1030-E1040.

19. Polak P, Cybulski N, Feige JN, Auwerx J, Rüegg MA, Hall MN. Adipose-specific knockout of raptor results in lean mice with enhanced mitochondrial respiration. Cell Metab. 2008;8(5):399-410.

20. Mizushima N, Yamamoto A, Matsui M, Yoshimori $\mathrm{T}$, Ohsumi Y. In vivo analysis of autophagy in response to nutrient starvation using transgenic mice expressing a fluorescent autophagosome marker. Mol Biol Cell. 2004;15(3):1101-1111.

21. Shiota C, Rocheleau JV, Shiota M, Piston DW, Magnuson MA. Impaired glucagon secretory responses in mice lacking the type 1 sulfonylurea receptor. Am J Physiol Endocrinol Metab. 2005;289(4):E570-E577.

22. Rorsman P, Salehi SA, Abdulkader F, Braun M, MacDonald PE. K(ATP)-channels and glucoseregulated glucagon secretion. Trends Endocrinol Metab. 2008;19(8):277-284.

23. MacDonald PE, et al. A K ATP channeldependent pathway within alpha cells regulates glucagon release from both rodent and human islets of Langerhans. PLoS Biol. 2007;5(6):e143.

24. Walker JN, Ramracheya R, Zhang Q, Johnson PR, Braun M, Rorsman P. Regulation of glucagon secretion by glucose: paracrine, intrinsic or both? Diabetes Obes Metab. 2011;13 Suppl 1:95-105.

25. Lantz KA, Vatamaniuk MZ, Brestelli JE, Friedman JR, Matschinsky FM, Kaestner KH. Foxa2 regulates multiple pathways of insulin secretion. JClin Invest. 2004;114(4):512-520.

26. Heddad Masson M, Poisson C, Guérardel A, Mamin A, Philippe J, Gosmain Y. Foxa1 and Foxa2 regulate $\alpha$-cell differentiation, glucagon biosynthesis, and secretion. Endocrinology. 2014;155(10):3781-3792.

27. Wang H, Gauthier BR, Hagenfeldt-Johansson KA, Iezzi M, Wollheim CB. Foxa2 (HNF3beta) controls multiple genes implicated in metabolismsecretion coupling of glucose-induced insulin release. J Biol Chem. 2002;277(20):17564-17570.

28. Lee CS, Sund NJ, Behr R, Herrera PL, Kaestner KH. Foxa 2 is required for the differentiation of pancreatic alpha-cells. Dev Biol. 2005;278(2):484-495.

29. Philippe J, Morel C, Prezioso VR. Glucagon gene expression is negatively regulated by hepatocyte nuclear factor 3 beta. Mol Cell Biol. 1994;14(5):3514-3523.

30. Stolovich-Rain $\mathrm{M}$, et al. Weaning triggers a maturation step of pancreatic $\beta$ cells. Dev Cell. 2015;32(5):535-545.

31. Thorel F, et al. Normal glucagon signaling and $\beta$-cell function after near-total $\alpha$-cell ablation in adult mice. Diabetes. 2011;60(11):2872-2882.

32. Gelling RW, et al. Lower blood glucose, hyperglucagonemia, and pancreatic alpha cell hyperplasia in glucagon receptor knockout mice. Proc Natl Acad Sci U S A. 2003;100(3):1438-1443.

33. Rorsman P, Ramracheya R, Rorsman NJ, Zhang Q. ATP-regulated potassium channels and voltage-gated calcium channels in pancreatic alpha and beta cells: similar functions but reciprocal effects on secretion. Diabetologia. 2014;57(9):1749-1761

34. Zhang Q, et al. Role of KATP channels in glucoseregulated glucagon secretion and impaired counterregulation in type 2 diabetes. Cell Metab. 2013;18(6):871-882.

35. Spigelman AF, Dai X, MacDonald PE. Voltagedependent $\mathrm{K}(+)$ channels are positive regulators of alpha cell action potential generation and glucagon secretion in mice and humans. Diabetologia. 2010;53(9):1917-1926.

36. Ramracheya R, et al. Membrane potentialdependent inactivation of voltage-gated ion channels in alpha-cells inhibits glucagon secretion from human islets. Diabetes. 2010;59(9):2198-2208.

37. Göpel SO, Kanno T, Barg S, Weng XG, Gromada $\mathrm{J}$, Rorsman P. Regulation of glucagon release in mouse -cells by KATP channels and inactivation of TTX-sensitive $\mathrm{Na}^{+}$channels. J Physiol (Lond). 2000;528(Pt 3):509-520.

38. Wang S, et al. Sustained Neurog3 expression in hormone-expressing islet cells is required for endocrine maturation and function. Proc Natl Acad Sci U S A. 2009;106(24):9715-9720.

39. Ritz-Laser B, Mamin A, Brun T, Avril I, Schwitzgebel VM, Philippe J. The zinc finger-containing transcription factor Gata- 4 is expressed in the developing endocrine pancreas and activates glucagon gene expression. Mol Endocrinol. 2005;19(3):759-770.

40. Artner I, et al. MafB: an activator of the glucagon gene expressed in developing islet alpha- and beta-cells. Diabetes. 2006;55(2):297-304.

41. Mastracci TL, et al. Nkx2.2 and Arx genetically interact to regulate pancreatic endocrine cell development and endocrine hormone expression. Dev Biol. 2011;359(1):1-11.

42. Paty BW, Ryan EA, Shapiro AM, Lakey JR, Robertson RP. Intrahepatic islet transplantation in type 1 diabetic patients does not restore hypoglycemic hormonal counterregulation or symptom recognition after insulin independence. Diabetes. 2002;51(12):3428-3434.

43. Rickels MR, et al. Glycemic thresholds for activation of counterregulatory hormone and symptom responses in islet transplant recipients. JClin Endocrinol Metab. 2007;92(3):873-879.

44. Marty N, et al. Regulation of glucagon secretion by glucose transporter type 2 (glut2) and astrocytedependent glucose sensors. JClin Invest. 2005;115(12):3545-3553.

45. Mori H, et al. Critical role for hypothalamic mTOR activity in energy balance. Cell Metab. 2009;9(4):362-374.

46. Mori H, et al. Critical roles for the TSC-mTOR pathway in $\beta$-cell function. Am J Physiol Endocrinol Metab. 2009;297(5):E1013-E1022.

47. Bernal-Mizrachi E, et al. Defective insulin secretion and increased susceptibility to experimental diabetes are induced by reduced Akt activity in pancreatic islet beta cells. JClin Invest. 2004;114(7):928-936.

48. Bernal-Mizrachi E, Wen W, Stahlhut S, Welling $\mathrm{CM}$, Permutt MA. Islet beta cell expression of constitutively active Akt1/PKB alpha induces striking hypertrophy, hyperplasia, and hyperinsulinemia. JClin Invest. 2001;108(11):1631-1638.

49. Dai XQ, et al. SUMOylation regulates insulin exocytosis downstream of secretory granule docking in rodents and humans. Diabetes. 2011;60(3):838-847.

50. Liss B, Bruns R, Roeper J. Alternative sulfonylurea receptor expression defines metabolic sensitivity of K-ATP channels in dopaminergic midbrain neurons. EMBO J. 1999;18(4):833-846.

51. Finak G, et al. MAST: a flexible statistical framework for assessing transcriptional changes and characterizing heterogeneity in single-cell RNA sequencing data. Genome Biol. 2015;16:278. 